University of New Hampshire

University of New Hampshire Scholars' Repository New Hampshire Agricultural Experiment Station New Hampshire Agricultural Experiment Station
Publications

$9-1-2006$

\title{
Distribution, morphology, and genetic affinities of dwarf embedded Fucus populations from the Northwest Atlantic Ocean
}

Arthur C. Mathieson

University of New Hampshire, Arthur.Mathieson@unh.edu

Clinton J. Dawes

University of South Florida

Aaron L. Wallace

University of New Hampshire

Anita S. Klein

University of New Hampshire, Anita.Klein@unh.edu

Follow this and additional works at: https://scholars.unh.edu/nhaes

Part of the Marine Biology Commons

\section{Recommended Citation}

Mathieson, Arthur C.; Dawes, Clinton J.; Wallace, Aaron L.; and Klein, Anita S., "Distribution, morphology, and genetic affinities of dwarf embedded Fucus populations from the Northwest Atlantic Ocean" (2006). Botanica Marina. 21.

https://scholars.unh.edu/nhaes/21

This Article is brought to you for free and open access by the New Hampshire Agricultural Experiment Station at University of New Hampshire Scholars' Repository. It has been accepted for inclusion in New Hampshire Agricultural Experiment Station Publications by an authorized administrator of University of New Hampshire Scholars' Repository. For more information, please contact Scholarly.Communication@unh.edu. 


\section{Distribution, morphology, and genetic affinities of dwarf embedded Fucus populations from the Northwest Atlantic Ocean}

\author{
Arthur C. Mathieson ${ }^{1, *}$, Clinton J. Dawes ${ }^{1,2}$, \\ Aaron L. Wallace ${ }^{3}$ and Anita S. Klein ${ }^{3}$ \\ ${ }^{1}$ Department of Plant Biology and Jackson Estuarine \\ Laboratory, University of New Hampshire, Durham, $\mathrm{NH}$ \\ 03824, USA, e-mail: arthur@hopper.unh.edu \\ 2 Department of Biology, University of South Florida, \\ Tampa, FL 33620, USA \\ ${ }^{3}$ Department of Biochemistry and Molecular Biology, \\ University of New Hampshire, Durham, NH 03824, USA \\ ${ }^{*}$ Corresponding author
}

\begin{abstract}
Dwarf embedded Fucus populations in the Northwest Atlantic Ocean are restricted to the upper intertidal zone in sandy salt marsh environments; they lack holdfasts and are from attached parental populations of $F$. spiralis or $F$. spiralis $\times F$. vesiculosus hybrids after breakage and entanglement with halophytic marsh grasses. Dwarf forms are dichotomously branched, flat, and have a mean overall length and width of 20.3 and $1.3 \mathrm{~mm}$, respectively. Thus, they are longer than Irish (mean $9.3 \mathrm{~mm}$ ) and Alaskan (mean $15.0 \mathrm{~mm}$ ) populations identified as F. cottonii. Reciprocal transplants of different Fucus taxa in a Maine salt marsh confirm that $F$. spiralis can become transformed into dwarf embedded thalli within the high intertidal zone, while the latter can grow into $F$. s. ecad lutarius within the mid intertidal zone. Thus, vertical transplantation can modify fucoid morphology and result in varying ecads. Microsatellite markers indicate that attached $F$. spiralis and $F$. vesiculosus are genetically distinct, while dwarf forms may arise via hybridization between the two taxa. The ratio of intermediate to species-specific-genotypes decreased with larger thalli. Also, F. s. ecad lutarius consists of a mixture of intermediate and "pure" genotypes, while dwarf thalli show a greater frequency of hybrids.
\end{abstract}

Keywords: distribution; dwarf embedded Fucus; ecology; genetics; morphology; salt marsh fucoid algae.

\section{Introduction}

Although species of Fucus (Heterokontophyta, Phaeophyceae) are typically differentiated by a variety of morphological and sexual criteria (Fritsch 1959, Powell 1963, Rice and Chapman 1985, Leclerc et al. 1998, Serrão et al. 1999, also Table 1), many of these taxa exhibit high levels of morphological plasticity that cause taxonomic confusion at both the intra- and interspecific levels (Bak- er and Bohling 1916, Burrows and Lodge 1951, Fritsch 1959, Powell 1963, Chapman and Chapman 1973, Russell 1978, Marsden et al. 1983, Norton and Mathieson, 1983, Pérez-Ruzafa and García 2000). Some investigators have postulated that there is a direct correlation between several environmental gradients (e.g., wave exposure, salinity, desiccation, temperature, and light availability) and phenotypic responses within individual species (Baker and Bohling 1916, Naylor 1936, Fritsch 1959, Russell 1978, 1987, Norton et al. 1981, Kalvas and Kautsky 1993, 1998, Chapman 1995, Ruuskanen and Bäck 1999, 2002). Others have suggested that genetic factors may also be important (Rice and Chapman 1985, Sideman and Mathieson, 1983, 1985, Munda and Kremer 1997, Anderson and Scott 1998, Scott et al. 2000, 2001). For example, Munda and Kremer (1997) found that vesiculated and evesiculated forms of $F$. vesiculosus $L$. can grow together in a patchwork of morphologies on Helgoland (German Bight, North Sea), and concluded that ecological factors alone were not sufficient to explain the observed morphological differences. Anderson and Scott (1998) and Scott et al. $(2000,2001)$ examined the presence of two distinct morphologies of $F$. spiralis $L$. that occurred as mixed stands [i.e. F. spiralis and F. s. f. nanus (Stackhouse) Børgesen], using both morphological characters and pyrolysis mass spectrometry, and concluded that the two morphologies should be formae (implying genetic differences) rather than environmentally induced morphotypes (cf. Russell 1978).

Morphological plasticity has also resulted in taxonomic confusion at the interspecific level within Fucus. The common occurrence of "intermediate" morphologies, where different species of Fucus grow together, has long been recognized. Such individuals are often regarded as interspecific hybrids (Thuret 1854, Sauvageau 1908a, Kniep 1925, Burrows and Lodge 1951, Boney 1966, Niemeck and Mathieson 1976, Bolwell et al. 1977, Evans et al. 1982, Scott and Hardy 1994, Hardy et al. 1998, Coyer et al. 2002), although the high degree of variation found within Fucus species has made confirmation using morphological characters difficult. Hybrid thalli tend to be found in narrow bands between different species of Fucus or in areas subject to recent environmental disturbance where the previous fucoid species have been displaced (Burrows and Lodge 1951, Boney 1966). For example, Scott and Hardy (1994) conducted morphological analyses similar to those of Burrows and Lodge (1951) and reported the presence of hybrids between belts of $F$. vesiculosus and $F$. spiralis. Thus, several workers have hypothesized that hybrids may be unable to effectively compete with parental forms under ordinary circumstances (Sauvageau 1909, Kniep 1925, Burrows and Lodge 1951, Boney 1966). Several lines of evidence 


\begin{tabular}{|c|c|c|c|c|c|c|c|c|c|}
\hline 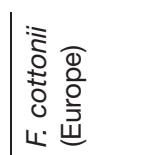 & 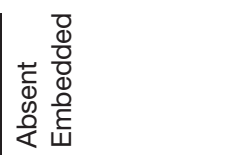 & 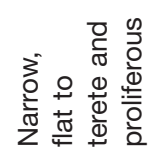 & 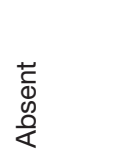 & 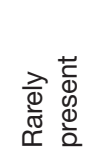 & $\begin{array}{l}\bar{\sigma} \\
\frac{\bar{\sigma}}{\bar{D}} \\
\frac{\bar{\sigma}}{2}\end{array}$ & 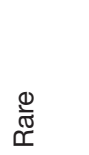 & 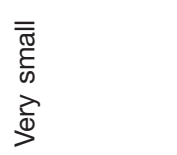 & 으 & 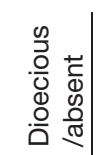 \\
\hline 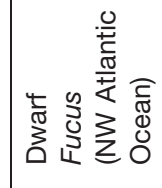 & 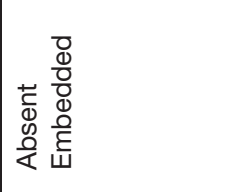 & 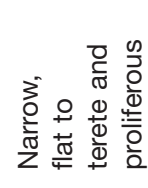 & $\begin{array}{l}\overrightarrow{\tilde{D}} \\
\mathbb{0} \\
\frac{0}{\alpha}\end{array}$ & 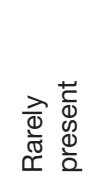 & 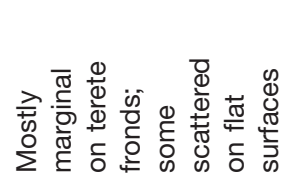 & 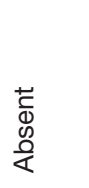 & 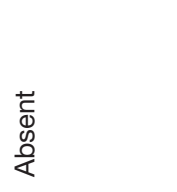 & 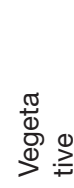 & 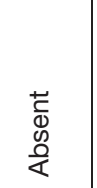 \\
\hline 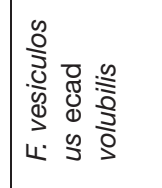 & 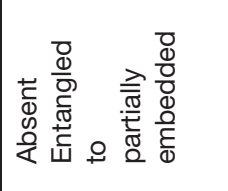 & 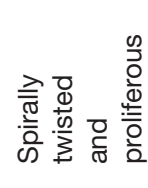 & 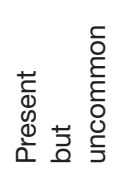 & 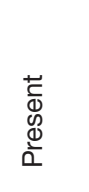 & 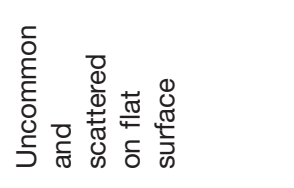 & 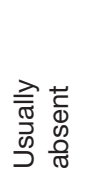 & 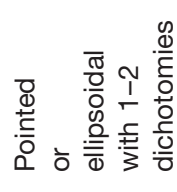 & $\frac{1}{2}$ & 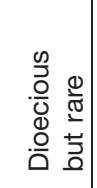 \\
\hline 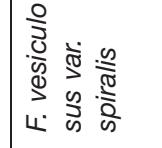 & 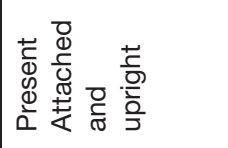 & 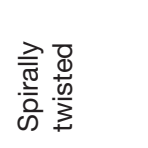 & 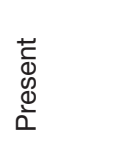 & 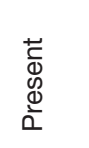 & 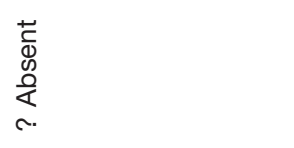 & 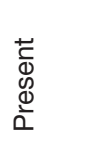 & $\frac{\frac{0}{0}}{\frac{0}{\frac{\pi}{\pi}}}$ & 을 & 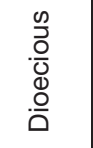 \\
\hline 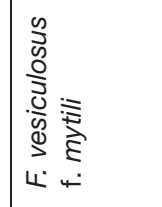 & 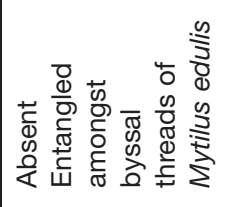 & 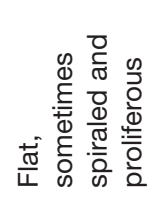 & 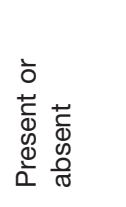 & 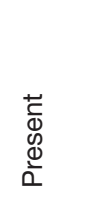 & 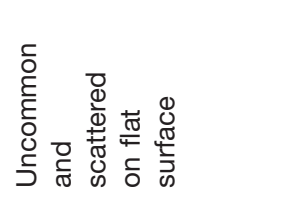 & 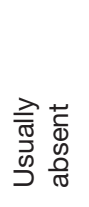 & 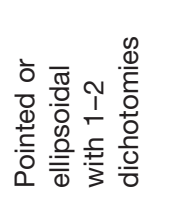 & 은 & 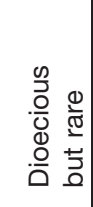 \\
\hline 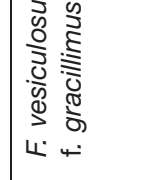 & 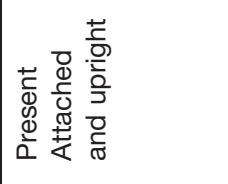 & 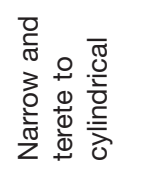 & $\begin{array}{l}\frac{\overrightarrow{0}}{0} \\
\Phi \\
\frac{0}{<}\end{array}$ & $\begin{array}{l}\underline{\underline{U}} \\
\stackrel{\underline{\underline{m}}}{\underline{\underline{m}}} \\
\underline{\underline{\underline{m}}}\end{array}$ & 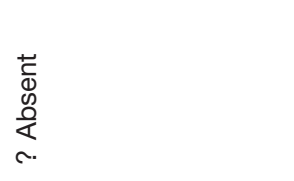 & 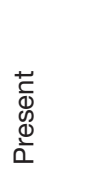 & 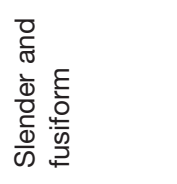 & zo & $\begin{array}{l}\stackrel{0}{0} \\
\frac{0}{0} \\
.0 \\
\frac{0}{0}\end{array}$ \\
\hline 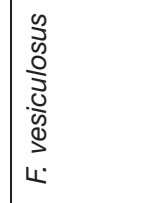 & 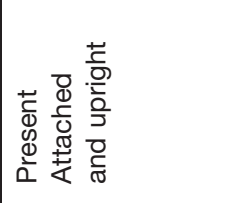 & 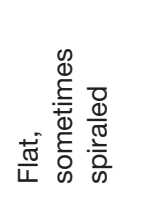 & 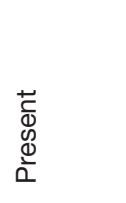 & 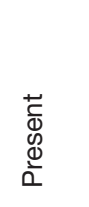 & 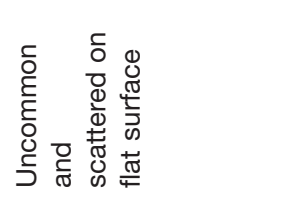 & 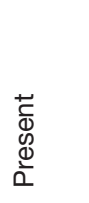 & 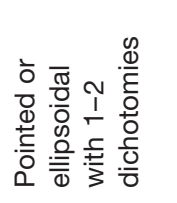 & z & $\begin{array}{l}\frac{0}{0} \\
\frac{0}{0} \\
\mathbb{0} \\
.0\end{array}$ \\
\hline 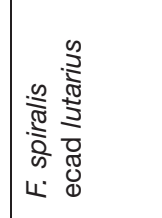 & 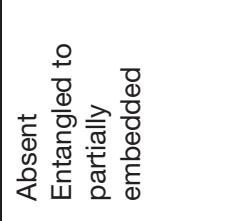 & 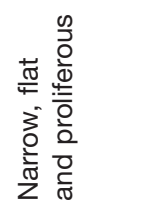 & 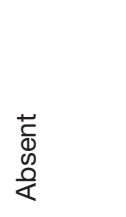 & 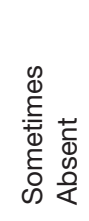 & 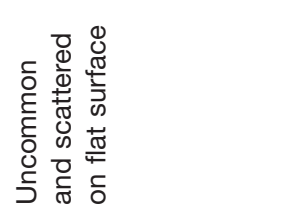 & 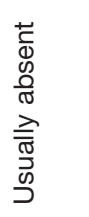 & 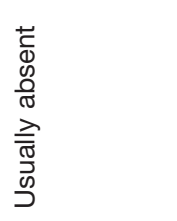 & 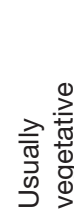 & 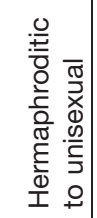 \\
\hline 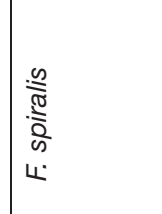 & 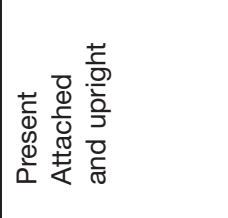 & 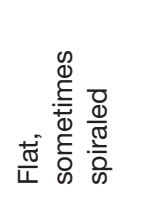 & 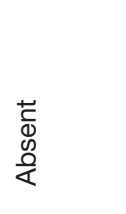 & 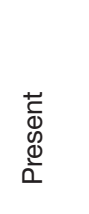 & 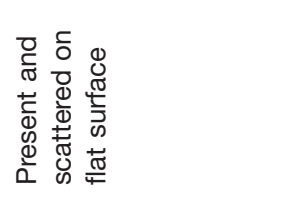 & 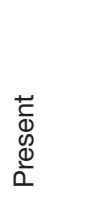 & 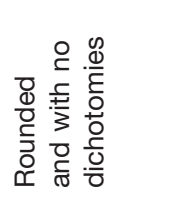 & $\stackrel{\infty}{\rightleftharpoons}$ & 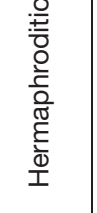 \\
\hline 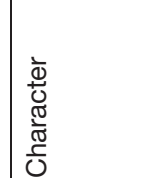 & 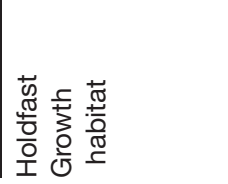 & 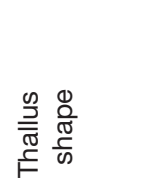 & $\begin{array}{l}\frac{0}{0} \\
\frac{0}{\mathscr{O}} \\
\stackrel{D}{\supset}\end{array}$ & $\frac{\text { 을 }}{\stackrel{\underline{\underline{y}}}{\Sigma}}$ & 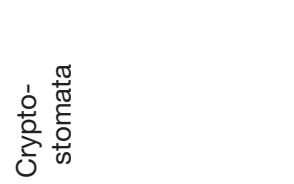 & 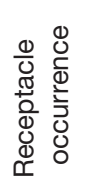 & 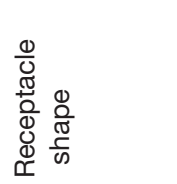 & 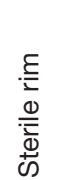 & 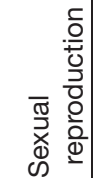 \\
\hline
\end{tabular}


support the likelihood of natural hybridization between different species of Fucus (Thuret 1854, McLachlan et al. 1971, Mathieson et al. 1981, Coyer et al. 2002). For example, Hardy et al. (1998) confirmed the identity of putative hybrids between $F$. vesiculosus and $F$. spiralis using pyrolysis mass spectrometry (cf. Russell 1995), while Coyer et al. (2002), using microsatellite markers, confirmed the presence of hybrids between $F$. serratus L. and F. evanescens C. Agardh in a zone of secondary contact.

Probably one of the most widely accepted species, taxonomy for the genus Fucus was created by Powell (1963) who grouped more than one hundred previously described species into six taxa ( $F$. ceranoides L., F. serratus, $F$. spiralis, $F$. vesiculosus, $F$. distichus L., and $F$. virsoides J. Agardh). Since then, several other taxa have been accorded independent status (e.g., F. cottonii Wynne et Magne 1991) or reinterpreted as distinct taxa (e.g. F. evanescens by Rice and Chapman, 1985). All six Fucus species initially classified by Powell (1963) usually grow attached (saxicolous), while at least four ( $F$. ceranoides, F. serratus, F. spiralis, and F. vesiculosus) may also give rise to detached salt marsh forms or ecads (Norton and Mathieson 1983, Mathieson and Dawes 2001) that may exhibit morphological variability due to their habitat (Clements 1905). By contrast, populations that exhibit phenotypic expressions due in part to genetic differences should be designated as ecotypes (Russell 1978 ) or various subspecific taxa (subspecies, variety, or formae).

As outlined by Norton and Mathieson (1983), detached salt marsh ecads can be placed in three major categories: (1) loose-lying or migration forms (cf. Rosenvinge 1898, Schiller 1909) that may occur directly on muddy banks of estuaries, (2) entangled forms that grow at the bases of marsh plants such as Spartina species, and (3) embedded forms that have their detached bases partly buried by mud or silt. Fucus ecads (Table 1) are characterized by holdfast absence (see above), spiraling of their thalli, extensive proliferation, a trend towards reduction in size, a loss of sexual reproduction, and enhanced vegetative proliferation (Baker and Bohling 1916, Fritsch 1959, Boney 1966, Chapman and Chapman 1973, Norton and Mathieson 1983). Ecads may arise via fragmentation of attached populations by several means, including ice rafting, herbivory, wave action, etc. (Chock and Mathieson 1976, Norton and Mathieson 1983). Fragments arriving in a depositional environment will grow, proliferate, and potentially produce more fragments. Alternatively, a zygote may become attached to an object that is insufficient to provide anchorage (a small stone or shell fragment) or is ephemeral (i.e., a rotting piece of wood or the roots or rhizomes of other salt marsh flora), leading to subsequent loss of a holdfast and detachment (Baker and Bohling 1916, Fritsch 1959, Boney 1966, Chapman and Chapman 1973). Norton and Mathieson (1983) also suggest that high salinities can inhibit the formation of rhizoids, giving rise to detached forms in salt marshes (cf. Torrey and Galun 1970).

As shown in Table 1 and Figure 1J, entangled Fucus ecads [e.g., F. vesiculosus ecad volubilis (Hudson) Turner] that grow entwined around the bases of salt marsh plants such as Spartina Schreb. tend to have spiraling or curling of their thalli, while spiraling is less pronounced or absent in smaller embedded (limicolous) forms (e.g., F. cottonii, Figure 2) that grow with their bases partly buried by mud, silt, or sand. Baker and Bohling (1916) suggest that spiraling in Fucus ecads is caused by salinity, differential nutrient access, and marginal growth of a thallus in contact with underlying muddy substrata. Norton and Mathieson (1983) also state that spiraling can be produced by a constant change of thallus orientation. Proliferation or extensive branching of a thallus can result from damage (Norton and Mathieson 1983), including burial during winter (Baker and Bohling 1916).

Embedded salt marsh Fucus ecads (Table 1) are detached populations that grow with their bases partly buried by mud, silt, or sand. They are usually found in the high intertidal zone where many seaweeds, including those with holdfasts, exhibit slow growth and a reduction in size (Norton et al. 1981). Baker and Bohling (1916) noted that shorter thalli are caused solely by exposure, whereas narrowing of the thallus is caused by low salinities. They hypothesized that these two factors can produce a morphological and ecological gradation from entangled to embedded forms along these two environmental gradients. Similarly, Brinkhuis (1976) observed a gradation in size between two ecads of Ascophyllum nodosum (L.) Le Jolis, mackaii Turner and scorpioides (Reinke) Hauck, with smaller forms found higher in the intertidal zone than larger ones. A reduction in size is especially frequent among embedded forms of Fucus, where gradual sedimentation results in partial burial of detached thalli followed by basal decay and rotting. When such burial reaches a dichotomy it will ultimately separate the thallus into two segments, a process also called "dichotomic splitting" (Den Hartog 1959, 1972). When combined with extensive proliferation, dichotomic splitting can give rise to dense carpets that are a common feature of these small limicolous forms (Figure 2).

Some investigators have reported receptacles on detached Fucus populations (Sauvageau 1908a, 1915, Cotton 1912, Baker and Bohling 1916, Skrine et al. 1932, Lynn 1935), others note that their gametes are often not viable (Gibb 1957, Norton and Mathieson 1983). Several investigators (Gibb 1957, Chock and Mathieson 1976) have also reported receptacles on recently detached material, which suggests that they are likely initiated prior to detachment. While the specific causes of inhibition or reduced sexual reproduction have not been identified, various causal factors have been suggested, including high humidity, decreased nutrient uptake or irradiance, exposure to biologically produced inhibitors, and reversion of the thallus to a juvenile state (reviewed by Norton and Mathieson 1983). Further, clonal reproduction is an efficient way to propagate copies of a genotype with proven survival abilities for a particular environment (Smith and Walters 1999).

Most Fucus ecads are probably derived from attached forms (Fritsch 1959). However, the relationships between these ecads are very difficult to determine using morphology alone, with such gradations being even more pronounced than those of saxicolous taxa (Figure 1). Hence, there are conflicting taxonomic treatments of 

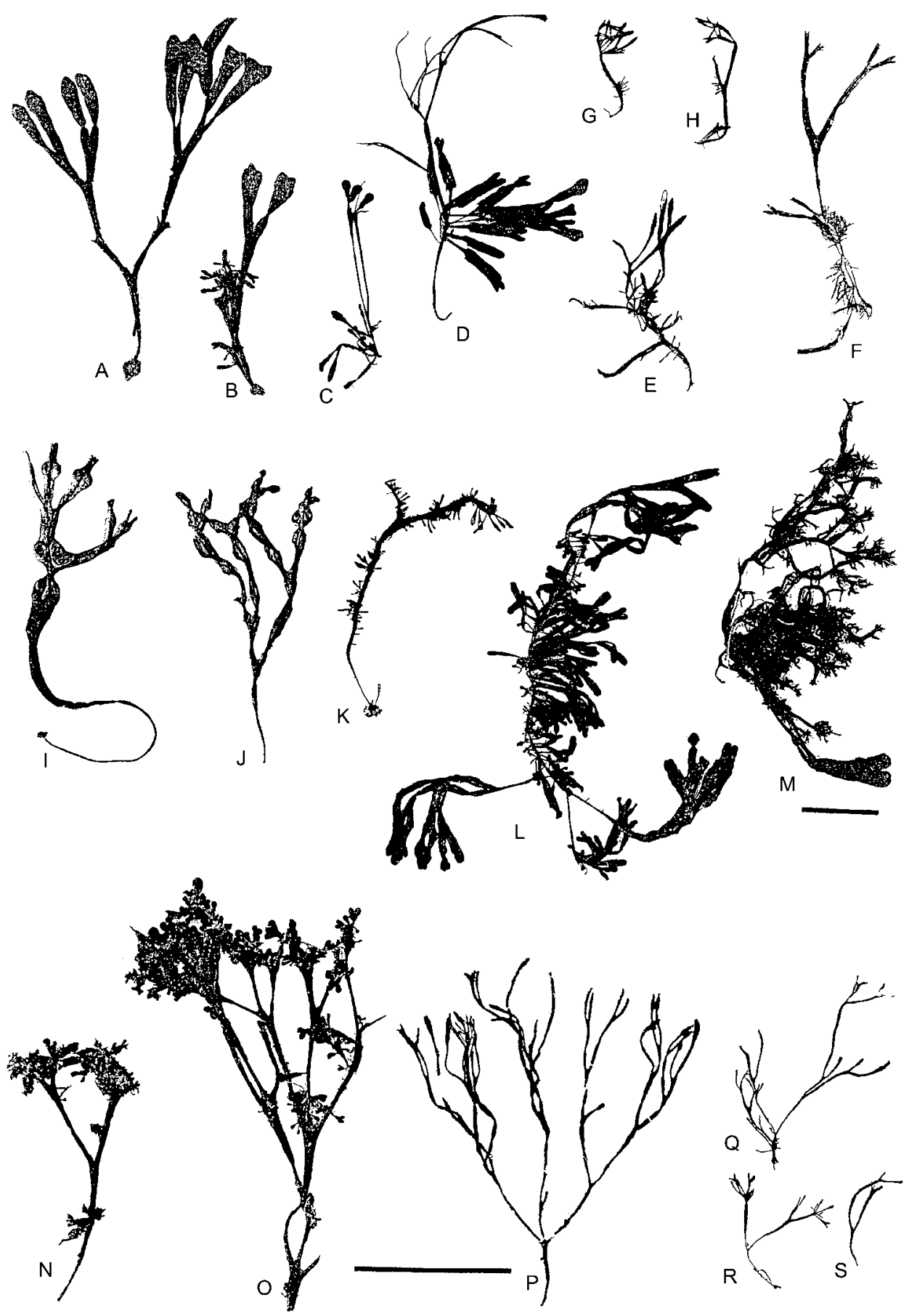

Figure 1 Silhouettes of various Fucus thalli from 25 Northwest Atlantic salt marshes showing morphological variability.

(A) An attached small thallus of $F$. spiralis. (B) A small attached proliferous thallus of $F$. spiralis. (C, D) Two eroded proliferous fragments of $F$. spiralis. (E, F) Two terete, narrow and highly proliferous vegetative fragments of $F$. spiralis ecad lutarius. $(G, H)$ Two small vegetative terete proliferous fragments of $F$. spiralis ecad lutarius. (I) A small attached vegetative thallus of $F$. vesiculosus var. spiralis with paired vesicles. (J) A spiraled vegetative fragment of $F$. vesiculosus ecad volubilis. (K) An attached, proliferous vegetative $F$. vesiculosus var. spiralis. (L) A fragment of $F$. vesiculosus ecad volubilis eroded to its midrib with many proliferations having wings and midribs. (M) A fragment of $F$. vesiculosus with terete, irregular proliferations and a residual foliar part. $(\mathrm{N}, \mathrm{O})$ Vegetative proliferous fragments of $F$. vesiculosus f. mytili that was attached to the blue mussel Mytilus edulis $L$. (P) A portion of a vegetative attached $F$. vesiculosus $\mathrm{f}$. gracillimus with narrow, parallel margins. (Q-S) Three detached terete fragments of $F$. vesiculosus $\mathrm{f}$. gracillimus. Scale, Figure $1 \mathrm{M}-\mathrm{O}$ $=2.5 \mathrm{~cm}$, other scale $=5.0 \mathrm{~cm}$.

fucoid ecads that are largely the result of four major factors: (1) delineation of taxa in a morphological continuum of different forms; (2) the possible convergence of morphology by ecads; (3) disagreement over the significance of specific character states; and (4) failure to provide evidence to justify changes in taxonomic rankings.
The most comprehensive attempt to simplify conflicting taxonomic delineations of detached/embedded Fucus populations was carried out by Baker and Bohling (1916) during an extensive survey of British salt marshes. They concluded that all estuarine Fucus taxa that lacked a holdfast were derived from $F$. vesiculosus, with the sole 

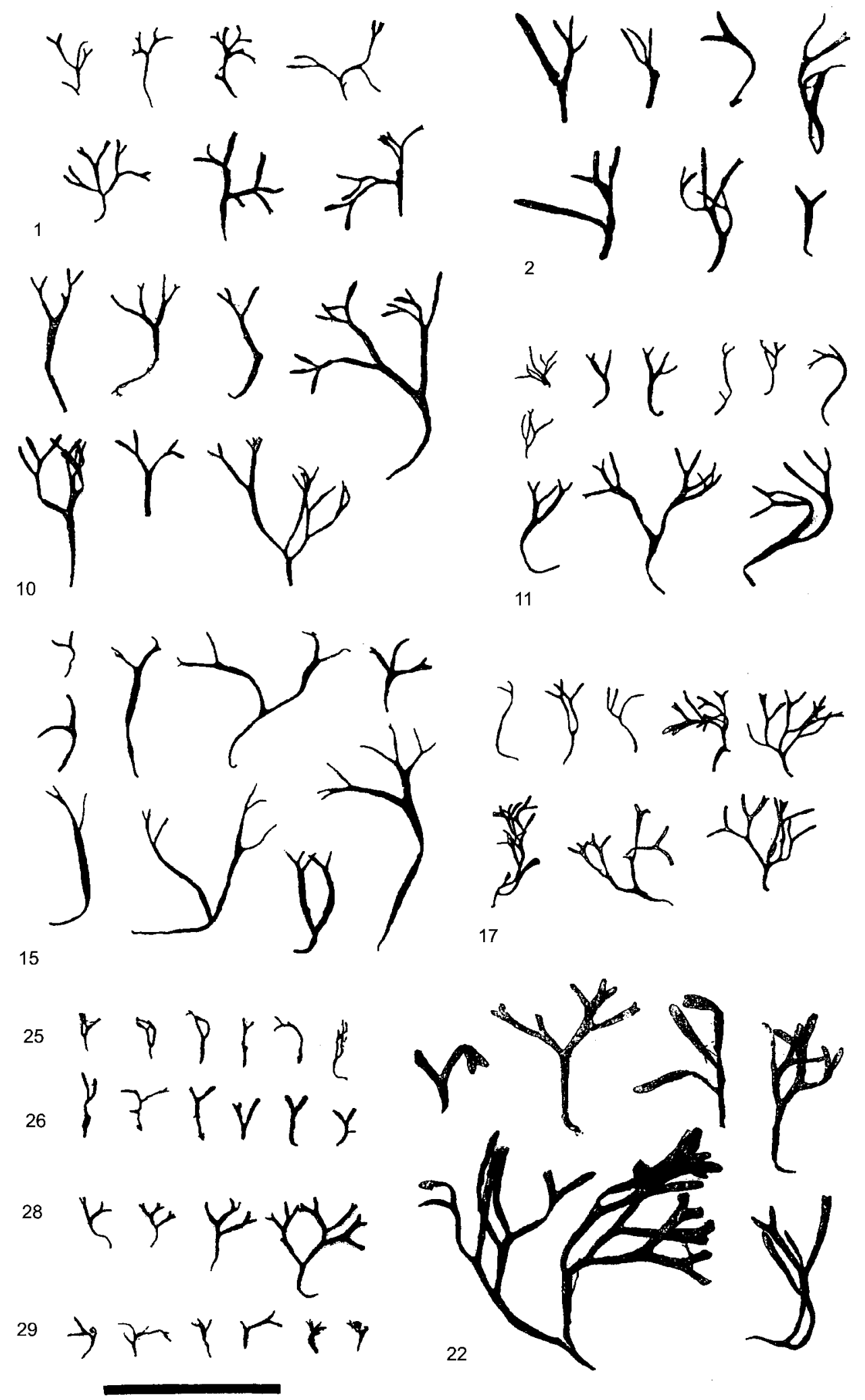

Figure 2 Silhouettes of dwarf embedded Fucus from 7 Northwest Atlantic salt marshes (sites 1, 2, 10, 11, 15, 17, and 22), plus two European marshes from Galway Bay, Ireland (sites 25 and 26) and two from Alaska (sites 28 and 29).

See Table 2 for site names and locations. Scale $=3 \mathrm{~cm}$.

exception of $F$. ceranoides. Their conclusions were based upon the presence of a morphological continuum connecting even the smallest embedded fragments to attached $F$. vesiculosus via intermediate entangled thalli, plus the usual dioecious/unisexual state of their receptacles when present. For convenience, Baker and Boh- ling (1916) recognized three taxa; F. v. ecad volubilis, ecad caespitosus Baker et Bohling, and ecad muscoides Baker et Bohling. These ecads were largely separated based on variability of the major morphological features noted above, and graded from ecad volubilis to ecad muscoides. However, transitional morphologies existed 
at the boundaries of these designated groups that could not be easily classified. Niell et al. (1980) noted an analogous pattern connecting these same three major ecads from a salt marsh in southwestern Spain, while Mathieson and Dawes (2001) found numerous transitional forms linking a muscoides-like dwarf Fucus to $F$. spiralis ecad lutarius (Kützing) Sauvageau (Figure 1e-h) in a southern Maine, USA salt marsh. The interpretation of morphological gradations has played a major role in the taxonomic status of dwarf embedded Fucus populations in European salt marshes, with these being listed as a variety (e.g., F. vesiculosus var. muscoides Cotton 1912), an ecad ( $F$. vesiculosus ecad muscoides; Baker and Bohling 1916, Niell et al. 1980), and a species (Parke and Dixon 1976), including F. muscoides (Cotton) Feldmann et Magne (1964) and F. cottonii Wynne and Magne (1991).

Convergent morphology is also an issue in ecad systematics. For example, the muscoides-like Fucus reported by Mathieson et al. (2001) and Mathieson and Dawes (2001) from Brave Boat Harbor, Maine is very similar to the ecad muscoides of Baker and Bohling (1916), although the two forms are apparently derived from different species (see below). The channel wrack Pelvetia canaliculata L. also appears to give rise to morphologies resembling dwarf embedded Fucus (e.g., P. canaliculata ecad muscoides, Skrine 1928, Carter 1933), while F. gardneri P.C. Silva has recently been described as producing a $F$. cottoni type thallus in the northeastern Pacific Ocean (Kucera and Saunders 2006, Serrão et al. 2006).

Disagreements regarding the value of specific character states have plagued the classification of Fucus ecads. For example, in Sauvageau's (1908a,b, 1923) studies of detached Fucus he recognized two species, $F$. lutarius Kützing (that lacked vesicles) and $F$. volubilis Hudson (a vesiculated form), and he argued that the former was most likely affiliated with $F$. spiralis. By contrast, Baker and Bohling (1916) placed F. lutarius in their ecad volubilis. Both arguments hinged largely on the weight given to the sexual state of the receptacles. Baker and Bohling (1916) argued that dioecious, unisexual receptacles favored an origin from $F$. vesiculosus, while Sauvageau $(1907,1908 a, 1915)$ proposed that since the receptacles were always female, this condition probably resulted from the reduction of a hermaphroditic to a dioecious state with a consequent loss of males. Also, Burrows and Lodge (1951) proposed that the sexual state of receptacles is the only diagnostic morphological trait separating $F$. vesiculosus and $F$. spiralis. These interpretations highlight the difficulty of classifying such variable forms and demonstrate the need for systematic assessments utilizing a combination of morphological, non-morphological (i.e., chemical and/or molecular), and transplant data. Unfortunately some transfers in taxonomic rankings have been carried out with little or no supporting evidence. Russell (1987), Norton and Mathieson (1983), and Colt (1999) cite several instances of such transfers in fucoid ecads, including the transfer of Cotton's (1912) F. v. var. muscoides to F. v. ecad muscoides by Baker and Bohling (1916), the elevation of $F$. v. ecad volubilis to ecotypic status by Davy de Virville (1944), the designation of detached $F$. spiralis populations as an ecad or variety lutarius by Chapman $(1939,1940)$, and the con- fused taxonomic status of dwarf limicolous Fucus discussed above. Mathieson and Dawes (2001) suggested that combined molecular, morphological, and ecological approaches (e.g., transplant and common garden experiments) are needed to help clarify the troublesome taxonomy of Fucus ecads.

The dwarf embedded or limicolous fucoid alga Fucus vesiculosus L. var. muscoides was initially reported by Cotton (1912) from the high intertidal zone of Irish salt marshes and named for its moss-like morphology. Subsequently, Baker and Bohling (1916) included var. muscoides within their megaecad limicola or salt marsh fucoids that lacked holdfasts, designating them as $F$. $v$. ecad muscoides, a name later used by Niell et al. (1980). Feldmann and Magne (1964) found an analogous taxon on the Basque coast of France and renamed it $F$. muscoides. As the binomial $F$. muscoides is a basionym for the red alga Acanthophora muscoides (Linnaeus) Bory, Wynne and Magne (1991) renamed it $F$. cottonii because of its distinctive dwarf morphology, restricted growth within the upper intertidal zone, and embedded habit. Thus, most early records of dwarf embedded Fucus are from Europe (Cotton 1912, Baker and Bohling 1916, Wynne and Magne 1991), while more recent records are from New England (Mathieson and Dawes 2001, as muscoides-like Fucus) and the northeastern Pacific Ocean (Ruiz et al. 2000, Kucera and Saunders, 2006, as F. cottonii). The Alaskan material was considered initially to be either cryptogenic (i.e., with unknown origins) or introduced (Ruiz et al. 2000), while recent molecular work suggests that it is derived from F. gardneri (Kucera and Saunders 2006). By contrast, New England populations may be associated with $F$. spiralis (Mathieson and Dawes, 2001) or F. vesiculosus $\times F$. spiralis hybrids (Wallace et al., 2004).

In the present study we compare the distribution, morphology, and ecology of dwarf embedded Fucus populations from 25 Northwest Atlantic sites and recent collections from Galway Bay, Ireland near Cotton's (1912) initial study site, and herbarium voucher samples from three Alaskan sites. Based on earlier ecological studies in Maine, we predicted that sandy salt marshes of the high intertidal zone like those in Brave Boat Harbor (Mathieson and Dawes, 2001) and Galway Bay would support dwarf embedded populations with similar morphologies. Reciprocal transplants of dwarf Fucus and F. spiralis at Brave Boat Harbor, Maine were conducted to assess phenotypic plasticity and possible interrelationships with various fucoid ecads. Two major hypotheses were proposed: (1) dwarf in situ populations of Fucus from the high intertidal zone can be transformed into $F$. spiralis ecad lutarius when transferred to lower elevations; (2) detached/fragmented F. spiralis can be changed into narrow entangled thalli (i.e., F. s. ecad lutarius) when transferred to the uppermost intertidal zone, and these in turn can grow into dwarf muscoides-like Fucus. Molecular affinities of 14 dwarf Northwest Atlantic populations were compared with those from Brave Boat Harbor (Wallace et al. 2004) and Ros Muc, Ireland (Wallace 2005, Wallace et al. 2005). We hypothesized that dwarf embedded Fucus populations throughout the Gulf of Maine (i.e., Nova Scotia to Cape Cod, Massachusetts) 
would have a genetic pattern similar to those found at Brave Boat Harbor that are composed primarily of hybrids between $F$. vesiculosus and $F$. spiralis (Wallace et al. 2004).

\section{Materials and methods}

Dwarf embedded Fucus populations in the Northwest Atlantic Ocean were documented based on several floristic studies conducted between 1965 and 2005 (Mathieson et al. 1993, 1996, 1998, 2001, 2003, Mathieson and Fralick 1972, Mathieson and Hehre 1986, Mathieson and Penniman 1986a,b, 1991). That is, seasonal collections of all conspicuous seaweeds at 995 sites were made in the intertidal and shallow subtidal zones of three geographic regions: (1) the Canadian Maritime Provinces (12 sites); (2) the Gulf of Maine (922 sites); and (3) southern New England/Long Island Sound (61 sites). Five of the twelve Canadian salt marsh sites were in New Brunswick and seven on Prince Edward Island. Approximately $68 \%$ of the sites from the Gulf of Maine were from Maine, $\sim 25 \%$ from New Hampshire, and $7 \%$ from northern Massachusetts (Mathieson et al., 2003). In the southern New England/Long Island Sound area, 13 sites were from Massachusetts (i.e., south of Cape Cod), 26 from Rhode Island, 16 from Connecticut, 7 from New York, and 4 from New Jersey. Overall, approximately $10 \%$ of the total sites ( 99) were from rocky open coastal sites, while the remainder $(\sim 896$ total) were estuarine habitats with varying amounts of mud or sand and hydrographic conditions ranging from outer estuarine to inner riverine locations. Dwarf Fucus occurred only at 25 estuarine sites (Table 2). Voucher specimens of all 25 populations were deposited in the Albion R. Hodgdon Herbarium at the University of New Hampshire (NHA).

Dwarf Fucus populations at seven of these 25 Northwest Atlantic sites were randomly sampled once during general collections; eight of the other 17 populations were collected by coring on 2-3 occasions, while the remaining 10 sites were sampled by cores on four or more occasions (Table 2). The most extensive seasonal samplings were in Maine, at Moose Cove and Brave Boat Harbor (Table 2, Figure 3). Paired sediment samples were taken using a steel tube $\left(11.3 \mathrm{~cm}^{2}\right)$ to extract $10 \mathrm{~cm}$ long cores for determination of percent water content and particle size distribution, as described by Mathieson and Dawes (2001). A minimum of two biomass cores were collected at these 18 sites. Core samples $(10 \mathrm{~cm}$ long by $95 \mathrm{~cm}^{2}$ ) were extracted by pounding a polyvinylchloride (PVC) tube into the marsh, cutting off the lower part of the core with a knife, placing the samples in individually labeled plastic bags, and returning them to the laboratory under ice. Macroalgae and flowering plants in each core were separated and their damp-dried biomass values converted to $\mathrm{g}$ dry wt. $\mathrm{m}^{-2}$ using a wet to dry weight conversion determined for each species. The range and mean biomass ( $g$ dry wt. $\mathrm{m}^{-2} \pm \mathrm{SD}$ ) of each taxon was summarized. Values for mean ( $\pm 1 \mathrm{SD}$ ), lengths, widths, and discolored (blackened) burial depths of 25 dwarf embedded Fucus samples/core were enumerated, i.e.,
50 total based upon two core samples. A summary of macroalgae and flowering plants found at each site was made, as well as an enumeration of their percent occurrence (e.g., 1 of 25 sites $=4.0 \%$ occurrence).

Transect studies were conducted during late May to mid July, 1998 at Reversing Falls, Wells Harbor, and Brave Boat Harbor, Maine (Figure 3, Table 2) to determine zonation and biomass patterns of dwarf fucoid populations. At each site two transects, 5-7 m in length, were run from the base of a marsh cliff (i.e., non-vegetated sediment) near a tidal channel to the high marsh composed primarily of Spartina patens (Aiton) Muhl. The transects were approximately $40 \mathrm{~m}$ apart. Elevational profiles were determined using a line level and a surveying rod (Dawes 1998), with vertical heights above or below mean low water (MLW) calculated from predicted tidal levels (Harbor Master Program, Version 3, Zihua Software, Marlboro, USA). Paired core samples were taken starting from the lower fucoid vegetation and extending into the dwarf Fucus zone (Mathieson and Dawes 2001).

A three-year (1998-2001) reciprocal transplant study was conducted at Brave Boat Harbor, Maine (site 14, Table 2) in order to assess phenotypic plasticity of dwarf embedded Fucus and F. spiralis as well as possible relationships with other fucoid ecads. Previously, the "shortterm" effects ( $\sim 1$ year) on transplanted saxicolous and ecad forms was assessed at the same site (Mathieson and Dawes 2001); these were extended to three years as several workers (Cotton 1912, Norton and Mathieson 1983) have noted that some unattached fucoid algae may take several years to differentiate following detachment. Vertical transfers of intact salt marsh plugs $(10 \mathrm{~cm}$ long $\times 95 \mathrm{~cm}^{2}$ ) with in situ populations of Fucus and Spartina taxa were moved from the high $(+3.4 \mathrm{~m}$ above MLW) to the mid intertidal zones (+ $2.0 \mathrm{~m}$ above MLW) and vice versa. That is, six cores consisting of dwarf in situ Fucus and Spartina patens were moved from the high to the mid intertidal zone (low transplant), while an analogous set of cores, which was primarily composed of $F$. spiralis and S. alterniflora Loisel., was moved from the mid to the high intertidal zone (high transplant). An initial comparison of in situ populations from both zones was made at the start of the study (May, 1998) utilizing duplicate cores from contiguous areas near the various transplants; subsequent samples of these same in situ populations were taken after 13 and 36 months in June, 1999 and May, 2001. The identification of the various Fucus populations was made based upon a variety of traits (Table 1), including general morphologies, the presence or absence of vesicles, sterile receptacular rims, and cryptostomata, dioecious versus hermaphrodictic reproductive features, their stature, branching pattern, general ecology, etc.

In establishing the various transplants, plugs of marsh peat were extracted from areas with other salt marsh fucoids and then replaced by experimental cores with intact plant materials (see above). The evacuated holes were initially filled with extra sediments, the experimental cores tamped down into the holes, and leveled with the contiguous surfaces. A section of plastic PVC tubing (95 $\mathrm{cm}^{2}$ in diameter and $\sim 2 \mathrm{~cm}$ long) was pressed around the cores to prevent vegetative intrusion. The 


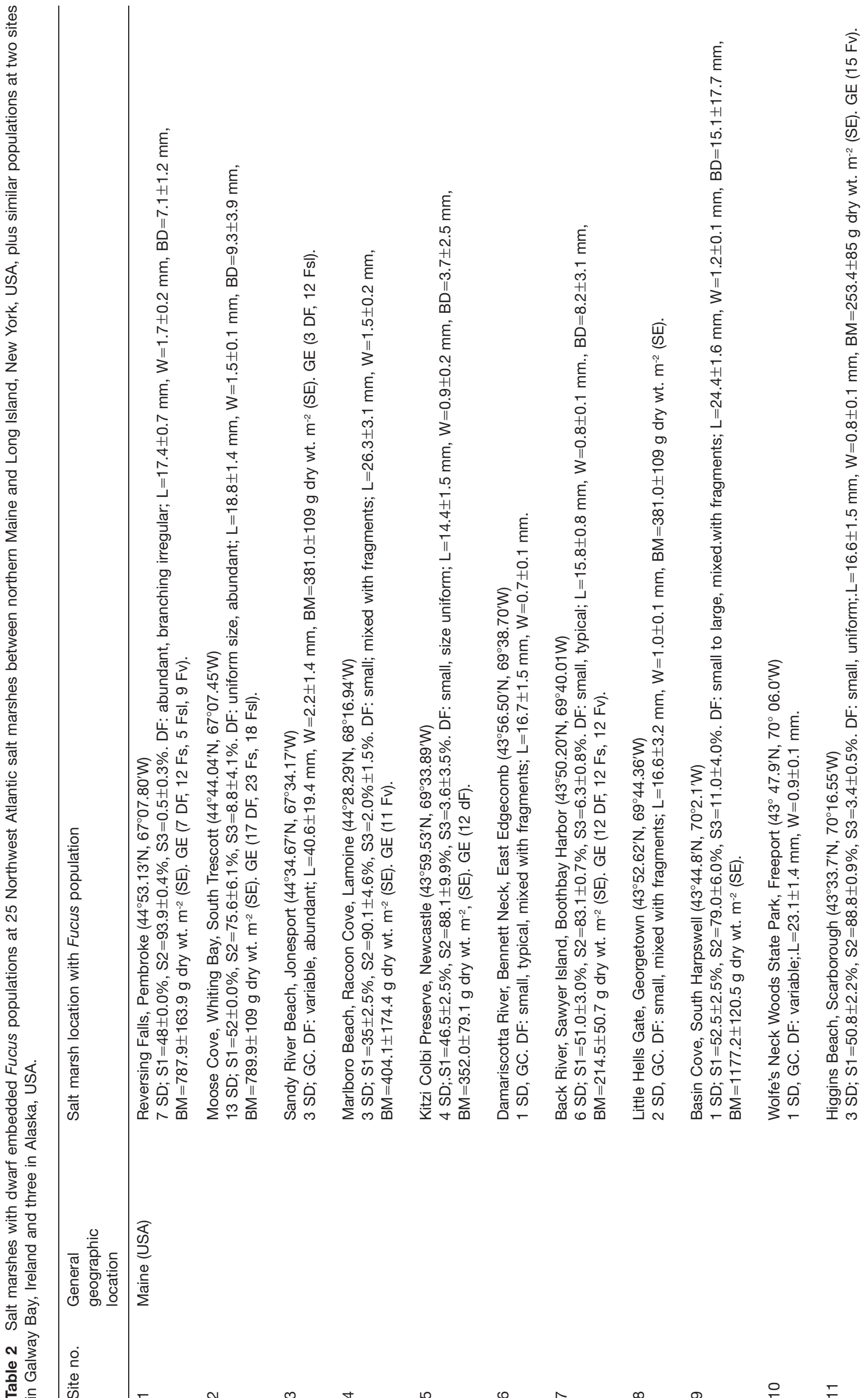




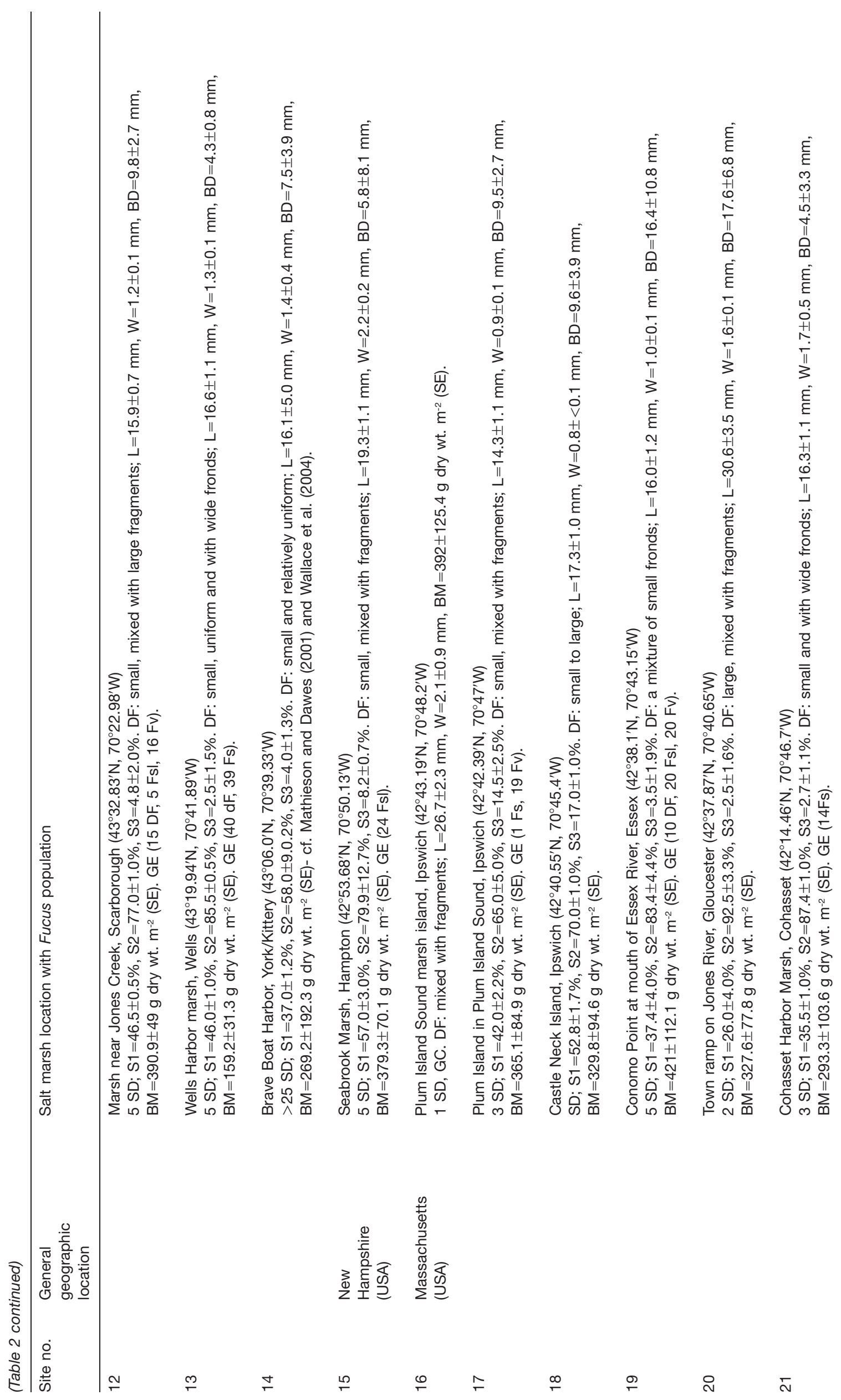




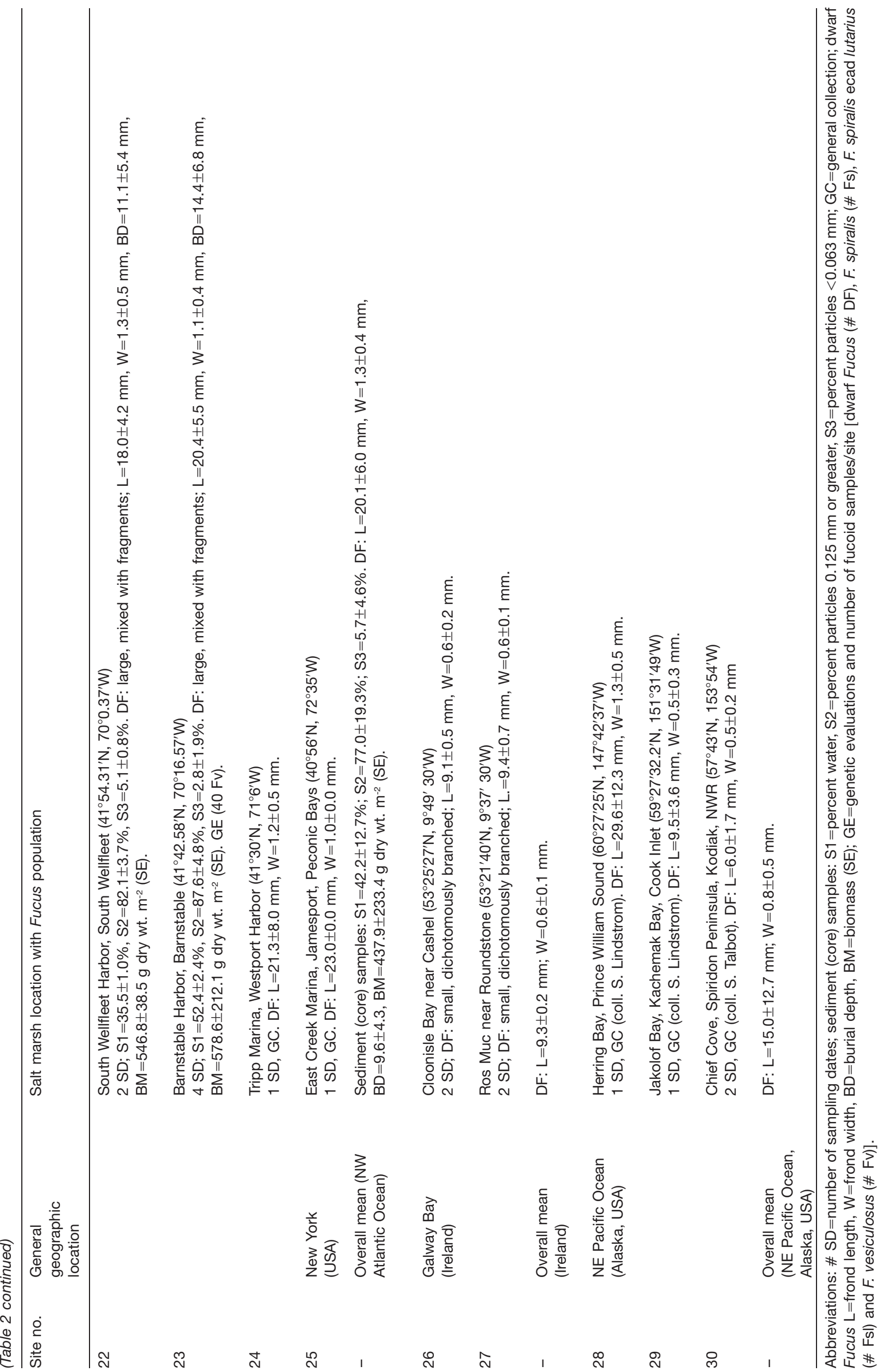




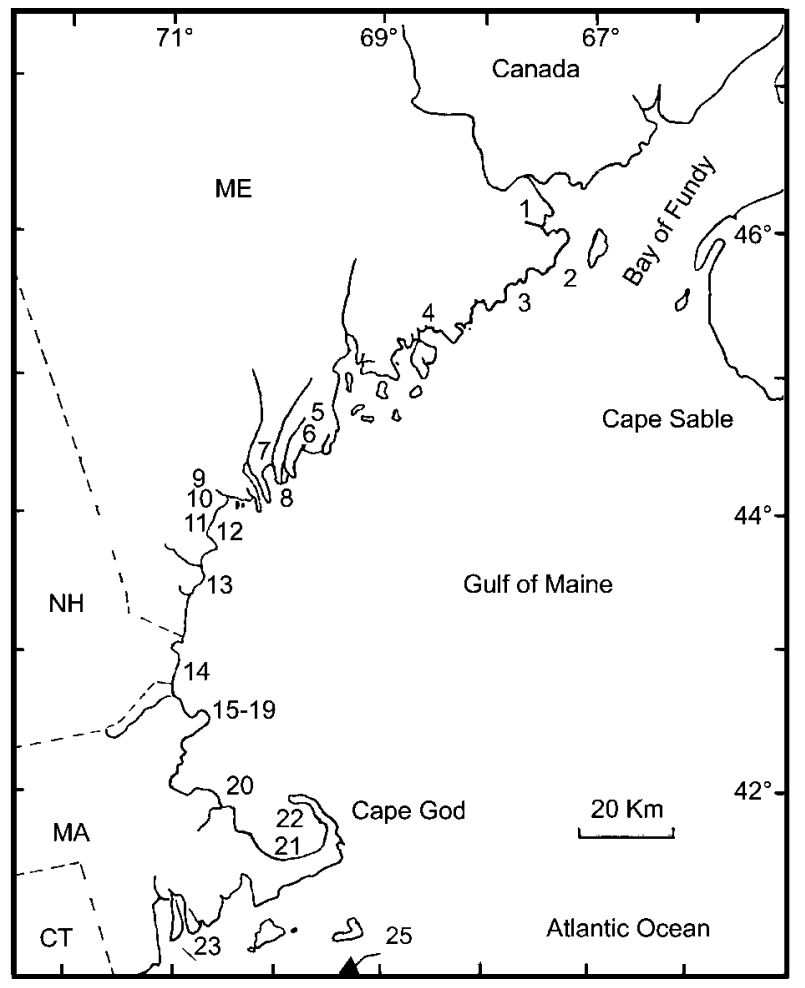

Figure 3 The Northwest Atlantic coast between the Canadian Maritime Provinces and Massachusetts-Connecticut showing 23 salt marshes plus the New York site (25, arrow) that contain dwarf embedded Fucus.

See Table 2 for site names and locations.

cores were then covered with plastic webbing and staked down with metal pins to prevent erosion. The experimental cores were easily relocated based on nearby PVC pipes and their PVC rings. A comparison of in situ and transplanted materials was made in May 1989, June 1999, and May 2001. A minimum of two cores was harvested for in situ upper and mid-intertidal populations, plus two cores for each of the upper and lower transplants. The core samples were washed, sieved, and sorted; the biomass ( $\mathrm{g}$ dry wt $\mathrm{m}^{-2}$ ) of Fucus and Spartina taxa was then enumerated and the length, width, branching patterns, and degree of proliferation of the various Fucus populations assessed. The mean length $( \pm S D)$ of 50 Fucus thalli per treatment was enumerated, based upon a pooling of fronds from both core samples.

Collections of dwarf embedded Fucus from Ireland were made during 1999 and 2004 at two sites in Galway Bay near Cashel and Roundstone, County Galway where Cotton (1912) conducted studies of Fucus vesiculosus var. muscoides ( $=$ F. cottonii). We also evaluated Alaskan collections designated as $F$. cottonii and deposited in the Algal Herbarium at the University of British Columbia (UBC): (1) Herring Bay, Prince William Sound (S. Lindstrom, September 16, 1989, mid to high intertidal drift, $60^{\circ} 27^{\prime} 25^{\prime} \mathrm{N}, 147^{\circ} 42^{\prime} 37^{\prime} \mathrm{W}$ ); (2) Jakolof Bay, Kachemak Bay, Cook Inlet (S. Lindstrom, July 3, 2003, 59 $27^{\prime} 32.2^{\prime} \mathrm{N}$, $\left.151^{\circ} 31^{\prime} 49^{\prime} \mathrm{W}\right)$; (3) Chief Cove, Spiridon Peninsula, Kodiak, NWR (S. Talbot, July 21 and August 9, 1990, 57 $43^{\prime} \mathrm{N}$, $153^{\circ} 54^{\prime} \mathrm{W}$ ). A comparison of the general morphologies, plus mean $( \pm S D)$ lengths and widths of approximately 50 fronds from each Irish and Alaskan location was made based on general collections or herbarium voucher specimens.

Collections of four Fucus taxa (dwarf Fucus, F. spiralis, $F$. spiralis ecad lutarius, and F. vesiculosus, Figure 1 and Table 1) were made during April-May, 2003 at fourteen Gulf of Maine sites having diverse Fucus ecads and representative habitats within this geography. Overall, 348 different Fucus samples were evaluated genetically: 97 dwarf embedded Fucus populations from nine sites, 64 specimens of $F$. spiralis from five locations, $85 F$. spiralis ecad lutarius from six sites, and $102 \mathrm{~F}$. vesiculosus from eight locations. The collections were returned to the laboratory on ice where the material was sorted (Table 1), cleaned, and prepared for DNA extractions after being rinsed thoroughly in distilled water and excising 5-10 mg of tissue from portions of thalli with no visible epiphytes. The tissue was then flash frozen in liquid nitrogen and stored at $-80{ }^{\circ} \mathrm{C}$ until DNA extraction using the Gentra Puregene ${ }^{\mathrm{TM}}$ DNA Isolation Kit (Gentra, Minneapolis, USA) and employing modifications discussed in Wallace et al. (2004). A single frond from a given "patch" of dwarf embedded Fucus was used for DNA extractions to prevent duplicate sampling. A similar approach was applied to $F$. spiralis ecad lutarius when applicable. Following DNA extraction, all samples were diluted 100 -fold prior to use.

Genotyping was done using the microsatellite markers developed by Wallace et al. (2004) as well as marker L94 of Engel et al. (2003). All polymerase chain reactions (PCR) were performed using fluorescent-labeled primers with amplification conditions and cycling parameters carried out as described by these respective authors. Following amplification, alleles were separated by polyacrylamide gel electrophoresis using an ABI373A automated DNA sequencer (Foster City, USA) and gels were analyzed using $\mathrm{ABI}$ GeneScan ${ }^{\mathrm{TM}}$ software version 3.1. Genetic clustering of morphologically identified taxa was performed with a multivariate factorial correspondence analysis in the Genetix software package (version 4.03, Belkhir 1999). The technique clusters samples according to genotype and the clusters can be compared to the initial morphological identifications to see how well they correspond. Individuals with missing (null) alleles and genotypes containing alleles present fewer than five times in the dataset were excluded from this analysis (Kotulas 1989).

\section{Results}

\section{Distribution, habitat, and associations of dwarf Fucus}

Dwarf embedded Fucus populations are uncommon within the Northwest Atlantic Ocean, being recorded at only 25 sandy salt marsh habitats (Figure 3, Table 2) or less than $3.0 \%$ of the 896 total estuarine sites evaluated. No dwarf populations were found at any rocky open coastal sites. In comparing geographical patterns, no dwarf embedded fucoids were found in the Canadian Maritime Provinces, 22 occurred in the Gulf of Maine (2.2\%), and two in southern New England and Long 
Island Sound (0.2\%). Thirteen of the Gulf of Maine sites were in Maine, one was in New Hampshire, and eight in northern Massachusetts. Single populations were recorded in both southern Massachusetts and New York. Dwarf embedded populations extended over $4^{\circ}$ of latitude, ranging from Reversing Falls, Maine $\left(44^{\circ} 53.13^{\prime} \mathrm{N}\right.$, $\left.67^{\circ} 07.8^{\prime} \mathrm{W}\right)$ to Jamesport, New York $\left(40^{\circ} 56^{\prime} \mathrm{N}, 72^{\circ} 35^{\prime}\right.$ W). Most populations grew in depositional environments that have large amounts (mean $82.9 \pm 7.8 \%$ ) of coarse sandy materials $(0.125 \mathrm{~mm}$ or more) and limited (mean $5.8 \pm 4.6 \%)$ silty or clay-like fractions $(<0.063 \mathrm{~mm})$. The mean water content of freshly collected sediments was relatively low $(45.1 \pm 8.5 \%$.).

Figure 4 illustrates the biomass zonation patterns for dwarf Fucus at three high intertidal sites ranging from site 1 in northern Maine and sites 13 and 14 in southern Maine (Figure 3, Table 2). The highest (4.5-6.3 $\mathrm{m}$ above MLW) and most vertically segregated populations were found on the two transects at site 1, a macrotidal site ( $7.0 \mathrm{~m}$ tidal amplitude). By contrast, lower and more circumscribed populations were found at the two southern mesotidal sites ( $\sim 2.6 \mathrm{~m}$ tidal amplitude), namely Wells Harbor (2.3-2.8 $\mathrm{m}$ above MLW) and Brave Boat Harbor (1.8-3.4 $\mathrm{m}$ above MLW). The biomass on the higher transect at Reversing Falls $(+5.4$ to $+6.3 \mathrm{~m}$ above MLW) was much greater (223-2074 g dry wt. $\mathrm{m}^{-2}$, mean $=1394.1 \pm 403.9 \mathrm{~g}$ dry wt. $\mathrm{m}^{-2}$, SE) than on the lower transect $(+4.5$ to $+4.9 \mathrm{~m}$ above MLW), which varied from $41.2-1027 \mathrm{~g}$ dry wt. $\mathrm{m}^{-2}$ (mean $=410.8 \pm 161.4 \mathrm{~g}$ dry wt. $\mathrm{m}^{-2}$, SE). By contrast, both the elevational profiles and biomass were much lower at Wells Harbor $(+2.3$ to +2.8 $\mathrm{m}$ above MLW, 34.7-288 $\mathrm{g}$ dry wt. $\mathrm{m}^{-2}$; mean = $113.3 \pm 44.7 \mathrm{~g}$ dry wt. $\left.\mathrm{m}^{-2}, \mathrm{SE}\right)$ and Brave Boat Harbor (+2.4 to +3.4 m above MLW, 22.0-258.0 g dry wt. $\mathrm{m}^{-2}$; mean $=136.5 \pm 46.0 \mathrm{~g}$ dry wt. $\left.\mathrm{m}^{-2}, \mathrm{SE}\right)$. Overall, the mean biomass value at Reversing Falls (804.2 \pm 750.0 SD g dry wt. $\mathrm{m}^{-2}$ ) was $\sim 5.9-7.1$ times greater than at Brave Boat and Wells Harbors.

Dwarf embedded Fucus were often mixed with detached-entangled fucoids (Figure 1, Table 1), including F. spiralis ecad lutarius (87.5\%) and Ascophyllum nodosum ecad scorpioides (87.5\%), plus attached populations of $F$. vesiculosus (83.3\%) and $F$. spiralis (70.8\%). The most frequent morphological variants of $F$. vesiculosus were $F$. v. ecad volubilis (54.2\%), F. v. forma gracillimus Collins (8.3\%), and F. v. forma mytili (Nienburg) Nienhuis or F. mytili Nienburg (8.3\%), with the last population occurring entangled amongst the byssal threads of the blue mussel Mytilus edulis (Parusel 1991). Drift fragments of $A$. nodosum (L.) Le Jolis and $F$. distichus $L$. emend Powell ssp. evanescens (C. Agardh) Powell (=F. evanescens of Rice and Chapman 1985) occurred at ten (41.7\%) and two sites (8.3\%), respectively.

Fourteen non-fucoid seaweeds were found growing with dwarf Fucus populations: 8 Chlorophyceae [Chaetomorpha linum (O.F. Müller) Kützing (8.3\%), Monostroma grevillei (Thuret) Wittrock (4.0\%), M. oxspermum (Kützing) Doty (4.2\%), Rhizoclonium riparium (Roth) Harvey (62.5\%), Ulva intestinalis L. (21.5\%), U. lactuca L (8.3\%), U. prolifera O.F. Müller (4.0\%), and Ulvaria obscura (Kützing) Gayral (4.0\%)], 3 Phaeophyceae [Melanosiphon intestinalis (Saunders) Wynne, Petalonia fascia (O.F. Mül- ler) Kuntze, and Scytosiphon lomentaria (Lynbgbye) Link, all three 4.0\%], 2 Rhodophyceae [Bostrychia radicans (Mont.) Mont. in Orbigny and Hypnea musciformis (Wulfen ex Jacquin) Lamour., both as 4.2\%], and 1 Xanthophyceae (Vaucheria, 62.5\%). Ten flowering plants were also present [Festuca rubra L. (4.0\%), Glaux maritima L. (8.3\%), Juncus gerardii Loisel. (4.2\%), Limonium nashii Small (45.8\%), Salicornia europaea L. (41.7\%), Spartina alterniflora (66.7\%), S. patens (70.8\%), Spergularia marina (L.) Griesb. (8.3\%), Suaeda maritima (L.) Dumort. (4.0\%), and Triglochin maritimum L. (20.8\%)]. Thus, $S$. patens, $S$. alterniflora, and the $R$. riparium/Vaucheria complex were the most frequently associated non-fucoid taxa.

The seven most common types of Fucus populations found in Northwest Atlantic salt marshes are shown in Figure 1. Fucus spiralis shows pronounced morphological variability, with fertile attached and eroded thalli (Figure 1A), attached proliferous populations (Figure 1B), and detached fragments of varying stature and proliferations (Figure $1 \mathrm{C}-\mathrm{H}$ ). The fragments in Figure 1C and 1D represent early transitional stages from attached proliferous thalli, while those in Figure $1 \mathrm{E}$ and $1 \mathrm{~F}$ illustrate later detached stages ( $=F$. spiralis ecad lutarius of some authors) that grade into dwarf embedded Fucus populations (Figure 1G, H). An analogous sequence from attached to detached fragments of $F$. vesiculosus is illustrated in Figure $1 \mathrm{I}-1 \mathrm{M}$, with attached (Figure 1I) and proliferous F. v. var. spiralis Farlow specimens (Figure $1 \mathrm{~K}$ ) grading into spiraled vegetative fragments typically identified as F. v. ecad volubilis (Figure 1J); these fragments subsequently become very proliferous, show foliar erosion along their midribs, and lose their vesicles (Figure $1 \mathrm{~L}$ and $1 \mathrm{M}$ ). The fragments then become reduced in size due to breakage, basal rotting, and dichotomic splitting, at which point they appear as "typical" dwarf embedded Fucus specimens (Figure 2). In comparing the two detached/entangled ecads $F$. s. ecad lutarius and $F$. v. ecad volubilis (Table 1), the former is distinguished from the latter as its fronds are narrower and show little spiraling. Typically, the average size of $F$. s. ecad lutarius is considerably smaller than F. v. ecad volubilis and unisexual receptacles (cf. Sauvageau 1907) are rare in the former and more common in the latter.

Two detached fragments of Fucus vesiculosus f. mytili are shown in Figure $1 \mathrm{~N}$ and 10; they grow entangled with byssal threads of Mytilus edulis and are proliferous and knobby. A portion of an attached specimen of $F$. vesiculosus f. gracillimus, which grows primarily in Cape Cod Bay, Massachusetts, is shown in Figure 1P. It has narrow parallel margins and inconspicuous linear to filiform receptacles unlike the broader $F$. $v$. var. spiralis (Figure 1I). Figure 1Q-1S shows small detached fragments of $F . v . f$. gracillimus that grade into dwarf embedded Fucus (Figure 1G, 1H and Figure 2).

\section{Morphological variability of dwarf Fucus}

Figure 2 illustrates the morphology of dwarf embedded Fucus populations from seven representative sites that range from northern-most Reversing Falls, Maine (site 1) to Barnstable Harbor, Massachusetts (site 22) near Cape Cod (Figure 3, Table 2). Dwarf Fucus thalli lack holdfasts, 

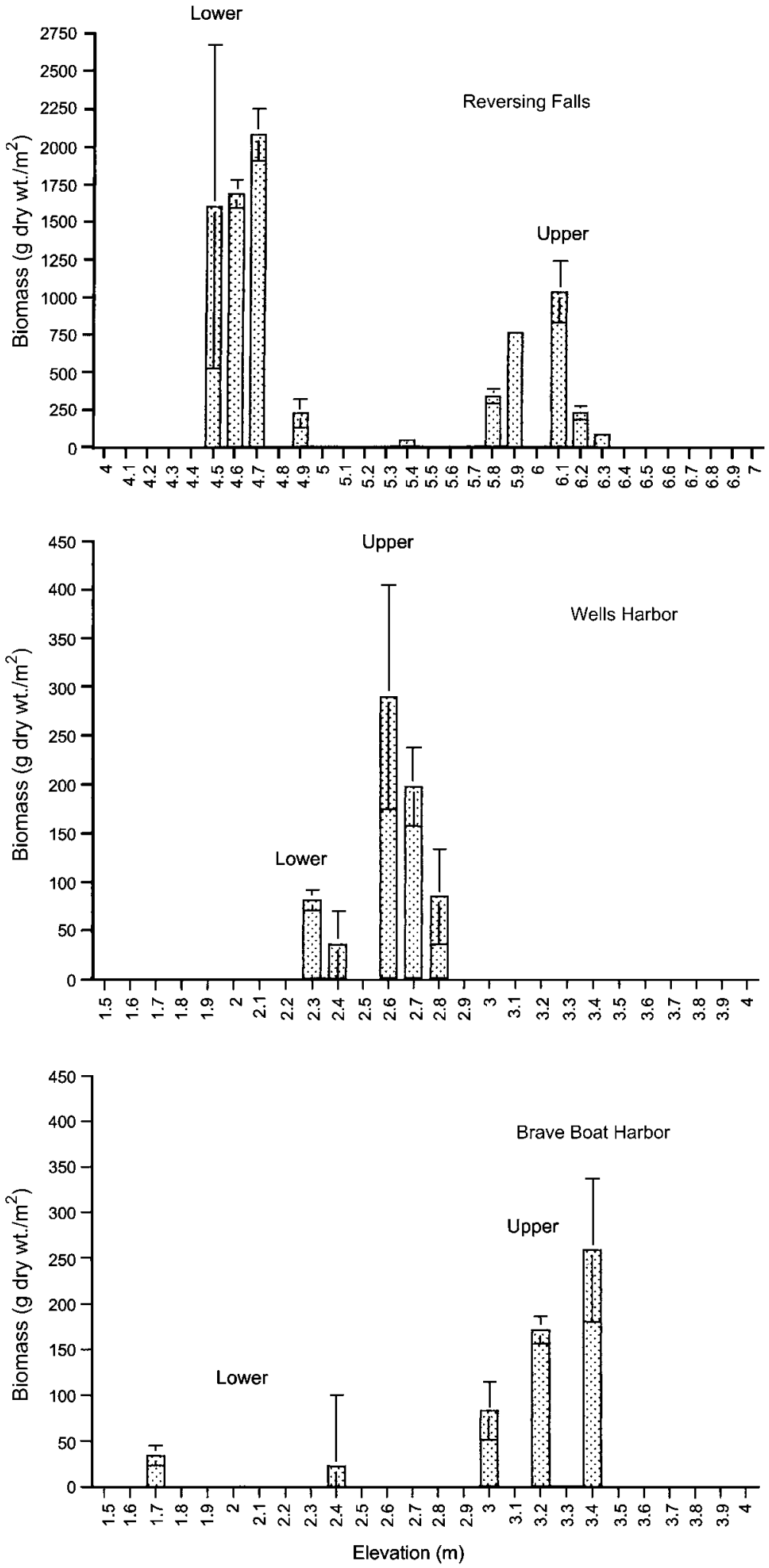

Figure 4 Zonation of high intertidal dwarf Fucus on upper and lower transects at Reversing Falls, Wells Harbor, and Brave Boat Harbor, Maine, expressed as biomass $\left(\mathrm{g}\right.$ dry $\left.w \mathrm{w} . \mathrm{m}^{-2}\right)$ at different heights $(\mathrm{m})$ above mean low water.

are embedded in sediments, and form moss-like turfs. All dwarf Fucus thalli have flattened, dichotomous, nonproliferous fronds that may or may not have a residual midrib. Conspicuous variation in size (e.g., sites 1 vs. 22), acuteness of branch tips (sites 11 vs 22), and regularity of branching (sites 2 vs. 17) is evident in Figure 2.
Frond lengths at the 25 study sites ranged from $14.3 \pm 1.1 \mathrm{~mm}$ at Plum Island, Massachusetts (site 16) to 40.6 $\pm 19.4 \mathrm{~mm}$ at Sandy River Beach, Maine (site 3), with an overall mean of $20.3 \pm 6.1 \mathrm{~mm}$ (Table 2). Frond width varied from $0.7 \pm 0.1 \mathrm{~mm}$ at the Damariscotta River in Maine (site 6) to $2.2 \pm 1.4 \mathrm{~mm}$ and $2.2 \pm 0.2 \mathrm{~mm}$ respec- 
tively at Sandy River Beach, Maine (site 3) and the Seabrook New Hampshire marsh (site 14), giving an overall mean of $1.3 \pm 0.5$ (Table 2). Frond burial ranged from 3.7 to $17.6 \mathrm{~mm}$ (mean $=9.8 \pm 4.4 \mathrm{~mm}$ ). Embedded Fucus populations from Cloonisle Bay and Ros Muc in Galway Bay, Ireland (sites 25, 26) were much smaller than those from the Northwest Atlantic Ocean and exhibited a more proliferous branching pattern. Irish samples averaged $9.1 \pm 0.5 \mathrm{~mm}$ and $9.4 \pm 0.7 \mathrm{~mm}$ in length and $0.6 \pm 0.2$ and $0.6 \pm 0.1 \mathrm{~mm}$ in width, respectively. Dwarf embedded Fucus populations from Alaska were highly variable, with mean values of $29.6 \pm 12.3 \mathrm{~mm}$ long and $1.3 \pm 0.5 \mathrm{~mm}$ wide at Prince William Sound $(n=7), 9.5 \pm 3.6 \mathrm{~mm}$ long and $0.51 \pm 0.3 \mathrm{~mm}$ wide at Jakolof Bay in Cook Inlet $(\mathrm{n}=37)$, and $6.0 \pm 1.7 \mathrm{~mm}$ long and $0.5 \pm 0.2 \mathrm{~mm}$ wide at Chief Cove, Spiridon Peninsula, Kodiak $(n=70)$, i.e. overall means of $15.0 \pm 12.7$ and $0.8 \pm 0.5 \mathrm{~mm}$, respectively.

\section{Biomass patterns}

Table 2 summarizes the mean biomass values for dwarf embedded Fucus at 25 sites, which ranged from $159.2 \pm 31.3 \mathrm{~g}$ dry wt. $\mathrm{m}^{-2}$ (site 13 ) to $1177.2 \pm 120.5 \mathrm{~g}$ dry wt. $\mathrm{m}^{-2}$ (site 9), with an overall mean of $435.5 \pm 224.1$ $\mathrm{g}$ dry wt. $\mathrm{m}^{-2}$. By contrast, attached $F$. vesiculosus f. gracillimus had a higher mean biomass value of $549.9 \pm 137.2 \mathrm{~g}$ dry wt. $\mathrm{m}^{-2}$, while the other six fucoid algae had lower, variable values, i.e., attached Fucus spiralis $\left(143.5 \pm 120.0 \mathrm{~g}\right.$ dry wt. $\left.\mathrm{m}^{-2}\right)$ and $F$. vesiculosus (178.0 $\pm 203.5 \mathrm{~g}$ dry wt. $\mathrm{m}^{-2}$ ), fragments of Ascophyllum nodosum $\left(92.7 \pm 62.0 \mathrm{~g}\right.$ dry wt. $\left.\mathrm{m}^{-2}\right)$, and entangled $A$. $n$. ecad scorpioides $\left(272.5 \pm 342.6 \mathrm{~g}\right.$ dry wt. $\left.\mathrm{m}^{-2}\right)$, F. s. ecad lutarius (195.5 $\pm 161.8 \mathrm{~g}$ dry wt. $\mathrm{m}^{-2}$ ), and $F$. v. ecad volubilis $\left(255.6 \pm 339.9 \mathrm{~g}\right.$ dry wt. $\left.\mathrm{m}^{-2}\right)$. Mean biomass values for attached non-fucoid seaweeds ranged from $8.0 \pm 2.8 \mathrm{~g}$ dry wt. $\mathrm{m}^{-2}$ for Ulva lactuca $\mathrm{L}$. to $220.5 \pm 223.5 \mathrm{~g}$ dry wt. $\mathrm{m}^{-2}$ for Melanosiphon intestinalis, while those for flowering plants varied from $55.6 \pm 5.2 \mathrm{~g}$ dry wt. $\mathrm{m}^{-2}$ to $2598.7 \pm 531.3 \mathrm{~g}$ dry wt. $\mathrm{m}^{-2}$ for Spergularia marina and Festuca rubra, respectively. The red fescue F. rubra was more local (4.0\% occurrence), while Spartina alterniflora and $S$. patens were more common (see above) and mean biomass values of $198.1 \pm 147.1 \mathrm{~g}$ dry wt. $\mathrm{m}^{-2}$ and $398.5 \pm 270.2 \mathrm{~g}$ dry wt. $\mathrm{m}^{-2}$, respectively.

The seasonal biomass for perennial dwarf embedded populations from Moose Cove, Maine (site 2) was maximal during fall $\left(1056.5 \pm 226.1 \mathrm{~g}\right.$ dry wt. $\left.\mathrm{m}^{-2}\right)$ and lowest in winter $\left(615.0 \pm 71.0 \mathrm{~g}\right.$ dry wt. $\left.^{-2}\right)$ and spring $\left(609.4 \pm 60.5 \mathrm{~g}\right.$ dry wt. $\left.\mathrm{m}^{-2}\right)$. A comparison of mean (790.0 $\pm 109.0 \mathrm{~g}$ dry wt. $\mathrm{m}^{-2}$ ) and maximum biomass values from Moose Cove showed that they were higher than most of the other Northwest Atlantic sites, except for Basin Cove site (site 9) in mid-coastal Maine $\left(1177.0 \pm 121.0 \mathrm{~g}\right.$ dry wt. $\left.\mathrm{m}^{-2}\right)$ and some of the individual transect records from Reversing Falls (1516.0-2074.0 $\mathrm{g}$ dry wt. $\mathrm{m}^{-2}$ ).

\section{Transplant experiment}

The 3-year (1998-2001) transplant experiment at Brave Boat Harbor, Maine (site 14) showed pronounced morphological changes of Fucus populations, particularly with respect to frond length, width, and branching patterns (Figures 5, 6a,b). For example, specimens resulting from the transfer of dwarf embedded Fucus thalli from the high to mid intertidal (i.e., low transplants) zones showed a conspicuous elongation $(13.5 \pm 4.6 \mathrm{~mm}$ to $59.2 \pm 28.3 \mathrm{~mm})$ and widening of their fronds $(1.0 \pm 0.3$ to $3.44 \pm 0.8 \mathrm{~mm})$, plus variation in proliferation, 1-year transplants (1999) being the most proliferous. After 3 years (2001), the low transplants were entangled with elongated parallel shaped fronds of moderate size and similar to F. spiralis ecad lutarius (Figure 1E, 1F). Some of the $F$. spiralis moved to the upper intertidal zone (high transplant) showed an initial detachment, breakage, and irregular morphology after 1 year (1999) that included a conspicuous reduction of frond length $(77.8 \pm 30.4 \mathrm{~mm}$ to $16.6 \pm 6.0 \mathrm{~mm})$ and width $(7.4 \pm 3.1$ to $0.7 \pm 0.2 \mathrm{~mm})$. The low transplants were initially more irregularly branched in 1999 than in 2001, while the high transplants were more regularly branched (i.e., dichotomous). After 3 years (2001), the high transplants were very similar to the dwarf thalli shown in Figures 2 and 5. Thus, transplants of $F$. spiralis that were moved to the high intertidal zone underwent detachment, breakage, and a reduction in length, leading to a dwarf morphology. By contrast, dwarf Fucus transplanted to the lower intertidal zone became enlarged and entangled, similar to $F$. s. ecad lutarius.

A comparison of biomass patterns for transplant materials showed some interesting patterns (Figure 6c). Foremost, dwarf Fucus thalli moved downwards showed a conspicuous decrease in biomass from $225.9 \pm 31.3$ (1998) to $33.3 \pm 47.0 \mathrm{~g}$ dry wt. $\mathrm{m}^{-2}$ (2001). New recruits of $F$. spiralis occurred on these cores during 1999 $\left(17.3 \pm 0.0 \mathrm{~g}\right.$ dry wt. $\left.\mathrm{m}^{-2}\right)$ and $2001(861.0 \pm 122.2 \mathrm{~g}$ dry wt. $\mathrm{m}^{-2}$ ) by attaching to the plastic screen covers. Mixed populations of Fucus also formed in the high intertidal transplant. Dwarf populations were first evident in high transplanted cores during $1999(506.4 \pm 0.0 \mathrm{~g}$ dry wt. $\mathrm{m}^{-2}$ ) and 2001 (221.9 $\pm 110.5 \mathrm{~g}$ dry wt. $\left.\mathrm{m}^{-2}\right)$. Attached low in situ populations of $F$. spiralis initially had biomass values of $188.0 \pm 117.3 \mathrm{~g}$ dry wt. $\mathrm{m}^{-2}$ (1998), while high transplants had $293.3 \pm 0.0$ and $221.9 \pm 110.5 \mathrm{~g}$ dry wt. $\mathrm{m}^{-2}$ during 1999 and 2001, respectively.

A comparison of in situ and transplanted biomass values for dwarf and attached $F$. spiralis showed that: (1) in situ mid-intertidal $F$. spiralis in 1999 amounted to 256.3 \pm $0.0 \mathrm{~g}$ dry wt. $\mathrm{m}^{-2}$, while the low transplants were $17.3 \pm$ $0.0 \mathrm{~g}$ dry wt. $\mathrm{m}^{-2}$; (2) in situ upper intertidal $F$. spiralis in 1999 was zero g dry wt. $\mathrm{m}^{-2}$, while the upper transplants were $293.3 \pm 0.0 \mathrm{~g}$ dry wt. $\mathrm{m}^{-2}$; (3) in situ mid intertidal $F$. spiralis in 2001 was $47.4 \pm 67.3 \mathrm{~g}$ dry $\mathrm{wt}^{\mathrm{m}} \mathrm{m}^{-2}$, while the low transplants were $861.0 \pm 122.2 \mathrm{~g}$ dry wt. $\mathrm{m}^{-2}$; (4) in situ upper intertidal $F$. spiralis in 2001 was zero $g$ dry wt. $\mathrm{m}^{-2}$, while the upper transplants were $146.7 \pm 159.6 \mathrm{~g}$ dry wt. $\mathrm{m}^{-2}$. Thus, a large quantity of $F$. spiralis apparently colonized the dwarf Fucus cores that were transplanted from the upper to the mid intertidal zone and some $F$. spiralis was maintained in the upper intertidal zone for two years, along with new populations of dwarf Fucus. By contrast, no in situ populations of $F$. spiralis were found in the upper intertidal zone and no in situ dwarf Fucus populations were recorded within the midintertidal zone. 


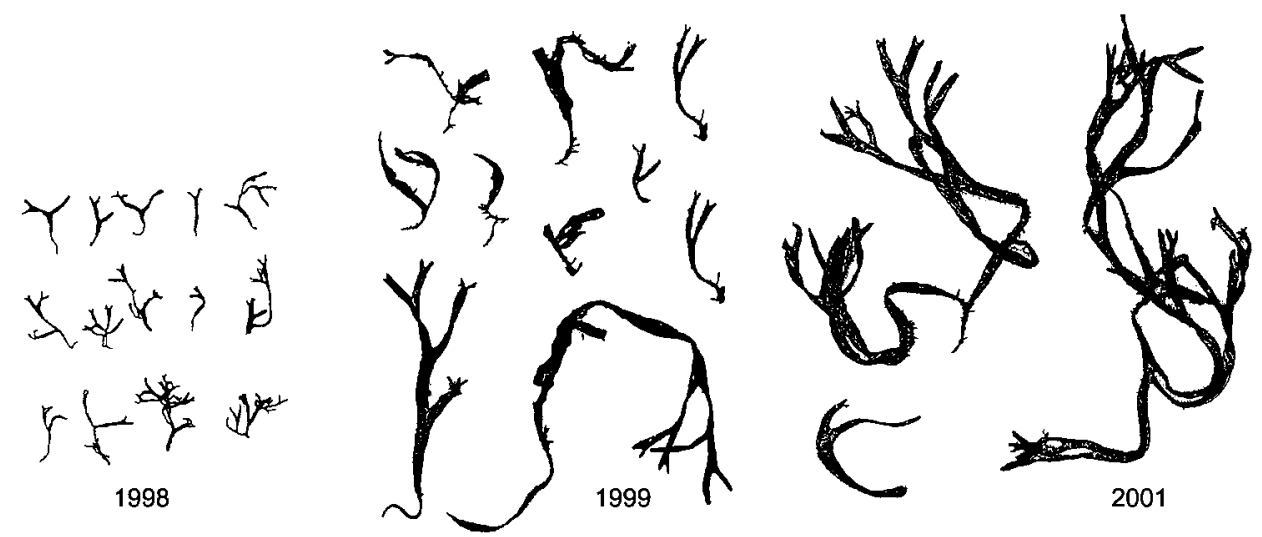

Lower transplant
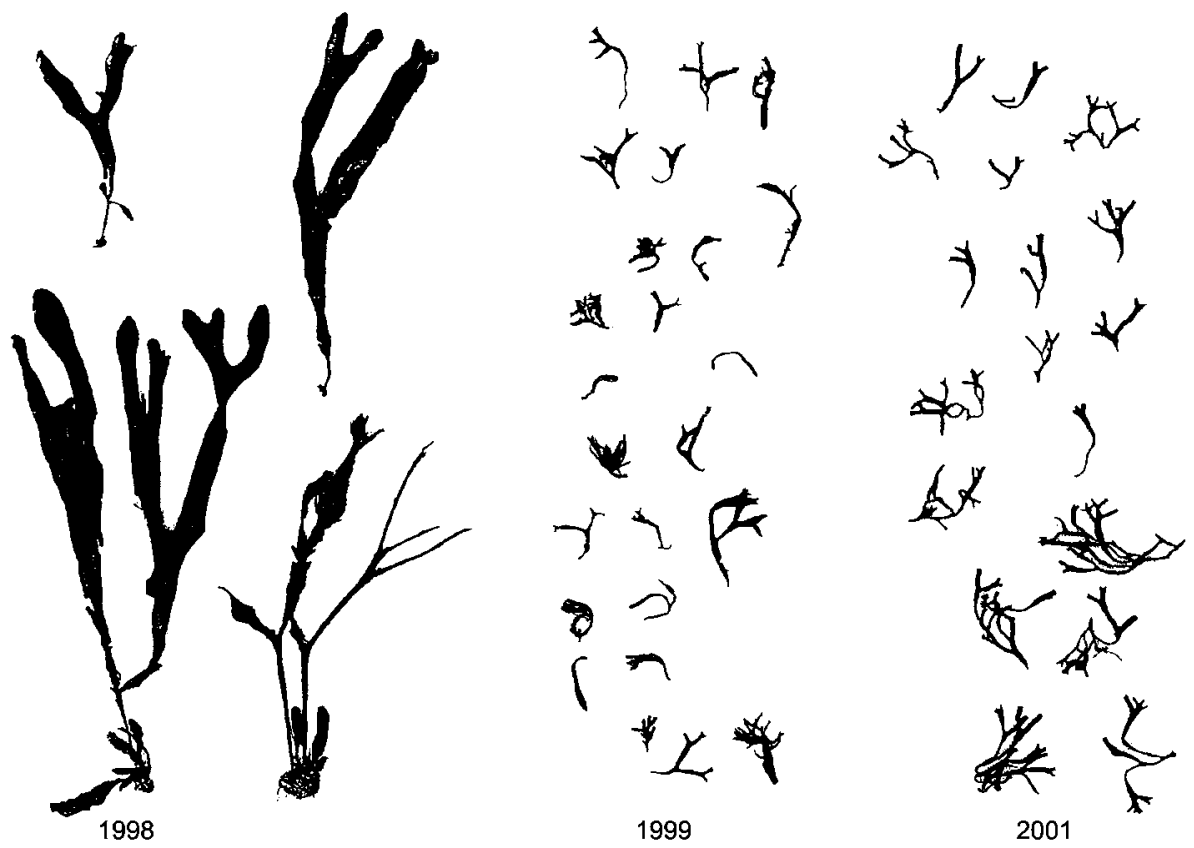

Upper transplant

Figure 5 Silhouettes of fucoid thalli observed during a 3 year (1998-2001) reciprocal transplant experiment at Brave Boat Harbor, Maine.

Upper transplant: transfer of in situ Fucus spiralis from the mid up to high intertidal. Lower transplant: transfer of in situ dwarf embedded Fucus down to the mid intertidal. Scale $=5.0 \mathrm{~cm}$.

\section{Genetic affinities of Gulf of Maine salt marsh Fucus}

Genotypic comparisons of the four morphologically separate Fucus taxa are shown in Figure 7, with each point representing a single genotype and identical genotypes sharing the same point. Fucus vesiculosus and F. spiralis were well separated along the $\mathrm{x}$-axis (representing factor one that captured $9.31 \%$ of the inertia), with the upper boundary of $F$. spiralis being $<-0.5$ along the $x$-axis and the lower boundary of $F$. vesiculosus $>0.25$. No samples identified as $F$. vesiculosus were found in the $F$. spiralis genotype cluster and only one of $F$. spiralis was found in the $F$. vesiculosus cluster. Thus, morphological and genetic identifications for each individual species were essentially identical when samples had clear-cut morphological traits, such as the presence of vesicles or hermaphroditic/unisexual receptacles (Table 1). Samples identified as $F$. s. ecad lutarius were scattered within the
F. vesiculosus and F. spiralis clusters from -1 to 1.0 along the $\mathrm{x}$-axis, but mostly located at an intermediate position between the clusters. Dwarf embedded genotypes were largely distinguished from $F$. s. ecad lutarius in that while the centers of each cluster along the $\mathrm{x}$-axis were fairly closely aligned, dwarf embedded Fucus were grouped more tightly along this axis (i.e., from approximately -0.25 to 0.5 ) and displayed much lower penetration into the $F$. spiralis and $F$. vesiculosus clusters than the latter taxa.

\section{Discussion}

The present study shows that populations of dwarf embedded Fucus occur throughout the Northwest Atlantic Ocean and are restricted to upper intertidal marshes with well drained medium to coarse sand, in association 

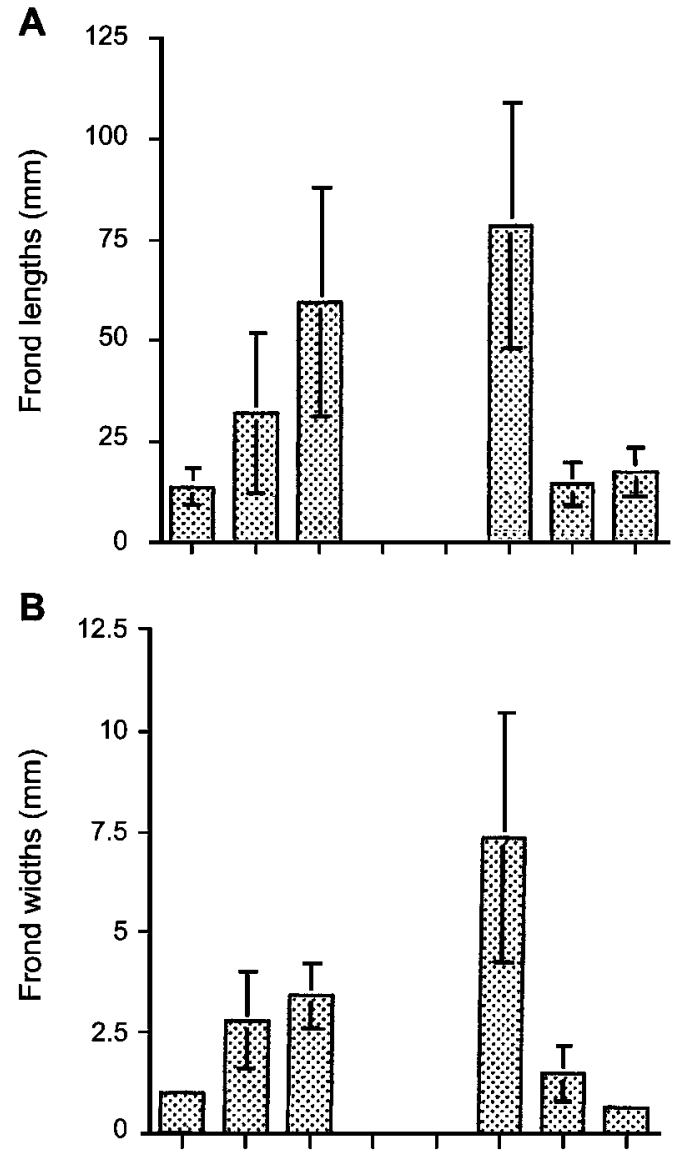

C

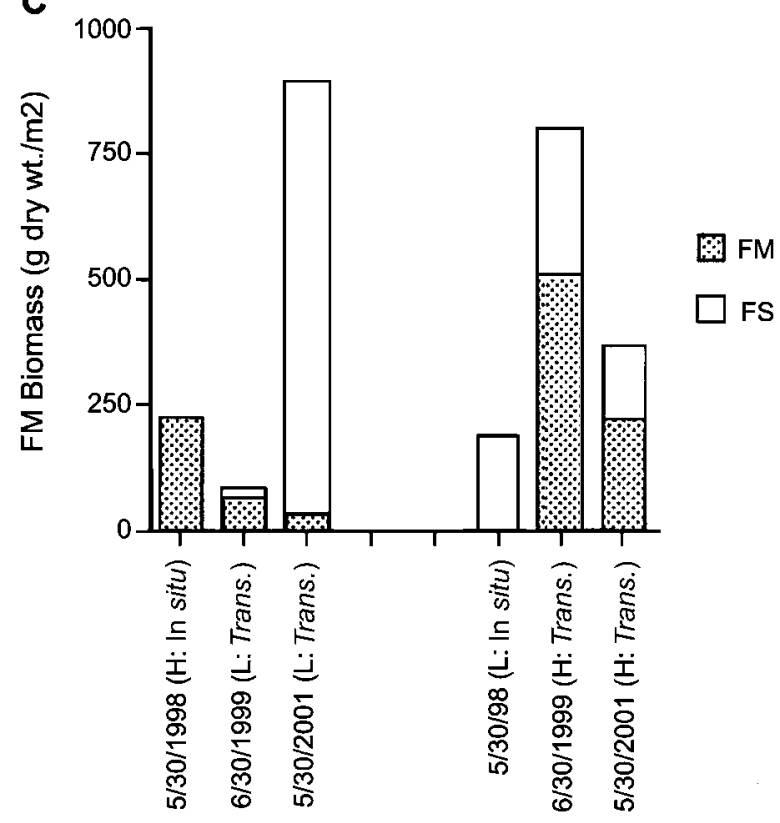

Dates/Treatments

Figure 6 Morphological and ecological comparisons of fucoid populations associated with a multi-year (1998-2001) reciprocal transplant experiment at Brave Boat Harbor, Maine.

Mean (mm $\pm \mathrm{SD}$ ) frond lengths (A) and widths (B) of high and low in situ thalli and transplanted populations, plus biomass variability ( $\mathrm{g}$ dry wt. $\mathrm{m}^{-2}$ ) for the same populations (C), i.e., muscoides-like Fucus (FM) and F. spiralis (FS).

with two halophytic flowering plants, Spartina alterniflora and S. patens. By contrast, the dominant flowering plants described by Cotton (1912) from Clair Island and
Roundstone in County Galway, Ireland were Armeria maritima (Miller) Willd. (as Statice maritima Miller), Puccinellia maritima (Huds.) Parl. [as Glyceria maritima (Hudson) Wahlb.], and Salicornia maritima Wolff et Jefferies, while the habitat was similar to that in the Northwest Atlantic Ocean. Based upon herbarium data, Alaskan dwarf embedded Fucus populations appear to grow at lower tidal levels than the Irish or Northwest Atlantic ones, and occur with other halophytic plants (Plantago maritima L., Triglochin maritima L.). According to Norton and Mathieson (1983) the halophytic plants aid in the initial entanglement and establishment of "parental" fragments at their bases, while their canopies also moderate desiccation within the high intertidal zone.

As noted, several unique Fucus ecads grow with dwarf embedded Fucus in the Northwest Atlantic Ocean. Fucus spiralis ecad lutarius [=var. lutarius (Kützing) Sauvageau in Taylor 1962] was relatively common. It had previously been recorded only from the Boston area of Massachusetts (Chapman 1939, 1940, Colt 1999), growing entangled with $F$. vesiculosus ecad volubilis and Ascophyllum nodosum ecad scorpioides. By contrast, attached and detached populations of Fucus vesiculosus f. gracillimus were more localized in the Cape Cod Bay area of southern Massachusetts (i.e. Barnstable County) near its type location (Collins 1900a,b; Phycotheca Boreali Americana No. 578). Typically it is less than $10 \mathrm{~cm}$ tall, has narrow $(1.5-2.5 \mathrm{~mm})$ evesiculate blades, an indistinct midrib, and slender, fusiform receptacles (Taylor 1962). Fucus vesiculosus f. mytili is newly recorded from the Northwest Atlantic region (Taylor 1962, Colt 1999, Sears 2002). Den Hartog (1959) considers the form (designated as F. mytili) to be "an anomalous form of the dioecious taxon F. vesiculosus", which agrees with our observations. Collins (1906) described another detached and entangled salt marsh fucoid, F. v. forma limicola, from Plymouth, southern Massachusetts that was slender, slightly twisted, evesiculate, and with small rounded conceptacles (Taylor, 1962). It has rarely been recorded (Colt 1999), perhaps because of confusion with other Fucus ecads. An evaluation of type material of $F$. v. forma limicola (i.e., Phycotheca Boreali Americana No. 1133) suggests that it may be a diminutive form of $F$. $s$. ecad lutarius. Small fragmented portions of detached and entangled $F$. $s$. ecad lutarius (including $F$. v. forma limicola), F. v. forma gracillimus, $F$. v. forma mytili, and $F$. v. ecad volubilis can grade into dwarf embedded populations (see Figures 1 and 2). A similar morphological convergence also occurs with Ascophyllum nodosum ecad scorpioides (Mathieson and Dawes 2001), F. gardneri (Kucera and Saunders, 2006), and Pelvetia canaliculata (Skrine 1928).

All dwarf embedded Fucus populations from the Northwest Atlantic region appeared moss-like, lacked holdfasts, and exhibited flat, dichotomously branched fronds. Thallus stature was highly variable, with mean frond lengths varying from 14.3-40.6 mm (grand mean $20.3 \pm 6.1 \mathrm{~mm}$ ) and mean width from $0.7-2.2 \mathrm{~mm}$ (grand mean $1.3 \pm 0.5 \mathrm{~mm}$ ); this contrasts with previously recorded dwarf Fucus populations from Brave Boat Harbor (Mathieson and Dawes 2001) that were shorter $($ mean $=13.2 \pm 4.2 \mathrm{~mm})$ and slightly thinner $(1.1 \pm 0.2 \mathrm{~mm}$ wide). Further, Maine dwarf Fucus were taller and wider 


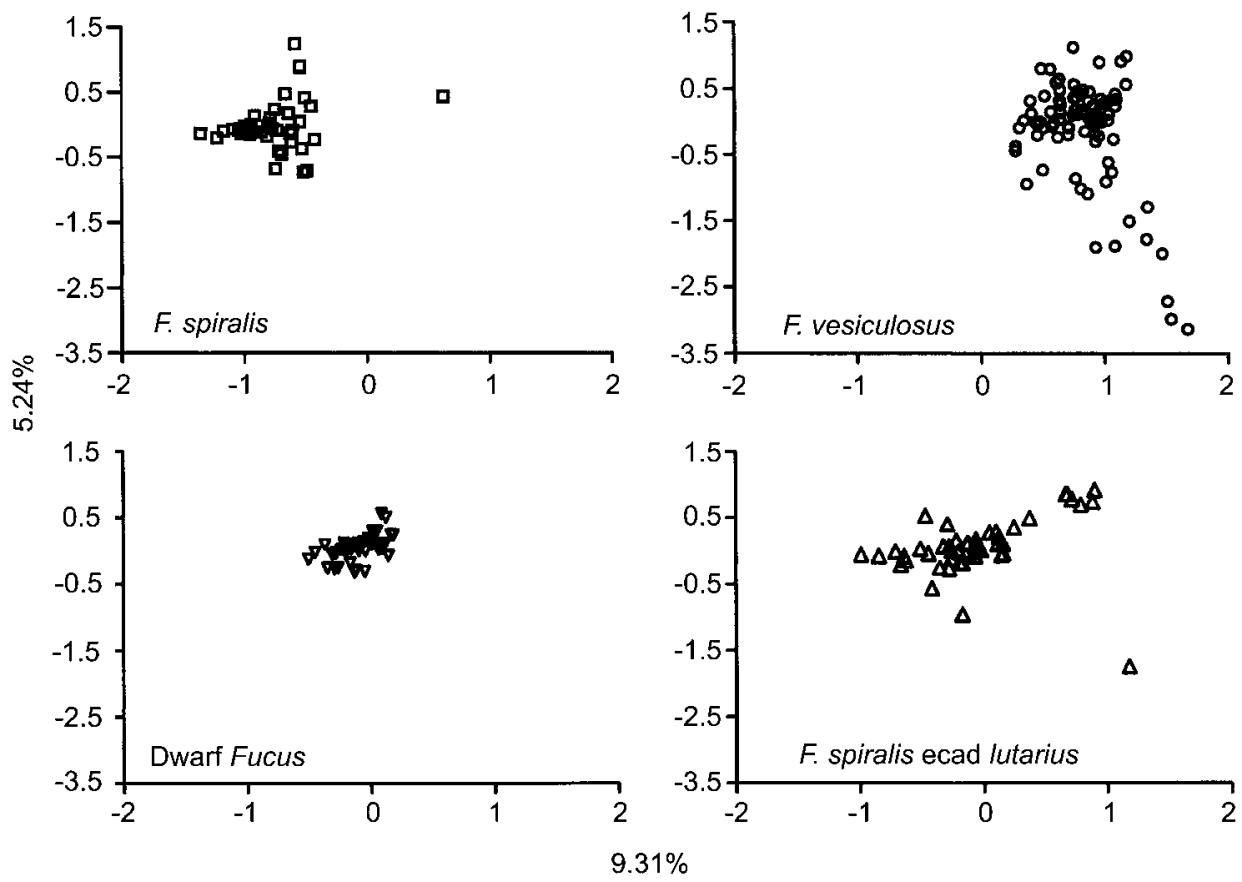

Figure 7 Factorial correspondence analysis of four taxa from the Gulf of Maine.

Genotypes are shown on 4 graphs with identical axes for comparison, with one taxon per graph. Each symbol represents one genotype, which may be shared between multiple individuals in some cases. Open squares, Fucus spiralis; open circles, F. vesiculosus; upside down open triangles, dwarf embedded Fucus; open triangles (right side up), F. spiralis ecad lutarius. The inertia values for both the $x$ - and $y$-axes are also shown.

than those collected during 1999 and 2004 from Galway Bay (mean $=9.3 \pm 0.2 \mathrm{~mm}$ long and $0.6 \pm 0.1 \mathrm{~mm}$ wide), but smaller than those described by Cotton (1912) from Clair Island (to 50-60 mm long and 1-3 mm wide). The two recent Galway Bay collections were also smaller than those described from England (Baker and Bohling 1916), Scotland (Lynn 1935), France (Feldmann and Magne 1964), and Spain (Niell et al. 1980). Alaskan dwarf Fucus showed a greater range of lengths $(6.0$ to $29.6 \mathrm{~mm}$, mean $=15.0 \pm 12.7 \mathrm{~mm}$ ) and widths $(0.5$ to $1.3 \mathrm{~mm}$, mean $=$ $0.8 \pm 0.5 \mathrm{~mm}$ ) than those from the Northwest Atlantic Ocean.

Cotton's illustration (1912: plate VI, figure 1) of Fucus vesiculosus var. muscoides ( $=F$. cottonii) showed specimens that were more variable in size, morphology (irregular proliferous branching), and fertility than those from the Northwest Atlantic Ocean (see Figure 2). Some of the Irish forms overlap with ecads of $F$. spiralis and F. vesiculosus from the Northwest Atlantic Ocean (see Figure 1). Differences in stature between Cotton's (1912) samples and our recent collections from Galway Bay may reflect varying habitat conditions, as the smallest dwarf Fucus thalli are usually found in the highest intertidal zone, while larger, entangled forms occur lower down. Several investigators (Baker and Bohling 1916, Lynn 1935, Niell et al. 1980) proposed a continuum in morphology between attached $F$. vesiculosus and dwarf embedded Fucus in Europe; a similar continuum was described by Mathieson and Dawes (2001) between attached F. spiralis, F. s. ecad lutarius, and dwarf Fucus in New England (see Figure 1). Mathieson and Dawes (2001) proposed that the dwarf embedded Fucus in Europe and New England are probably derived from dif- ferent attached species and should not be designated as the same taxon, F. cottonii.

In discussing dwarf embedded Fucus from the Northeast Pacific Ocean, it should be noted that $F$. vesiculosus is absent, while F. gardneri P.C. Silva and F. spiralis are present (Scagel et al. 1993, O'Clair and Lindstrom 2001, Kucera and Saunders 2005, 2006). Fucus spiralis thalli in the Northeast Pacific Ocean grow in the high intertidal zone like those in the North Atlantic Ocean, while F. gardneri occurs in the mid-intertidal zone. Kucera and Saunders (2006) noted that the shoreline in between these two extremes supports populations that display morphological features of both species. They suggested that this could result from phenotypic plasticity of one or both species, interspecfic hybridization, or morphological expressions of a single species at varying heights. Using a DNA barcode marker (ca. 600 bp of mitochondrial cytochome oxidase I gene) and the nuclear internal transcriber spacer gene (ITS), they found that intermediate morphologies were primarily $F$. gardneri and there was no evidence of hybridization. They also found that individuals of $F$. cottonii morphology were attributable to $F$. gardneri.

The 3-year reciprocal transplant studies at Brave Boat Harbor confirmed one of our major hypotheses, namely that dwarf in situ Fucus populations from the high intertidal zone can transform into $F$. spiralis ecad lutarius when transferred to the mid intertidal zone. Both the stature and degree of proliferation of transplanted thalli increased at lower elevations (see Figure 5), similar to in situ populations from other Northwest Atlantic sites. A second hypothesis suggested that attached $F$. spiralis moved from the mid to the high intertidal zone could be 
transformed into narrow entangled thalli (i.e., F. s. ecad lutarius) and eventually into dwarf embedded Fucus populations. This was only partially confirmed. Thus, when attached $F$. spiralis thalli were transplanted to the high intertidal zone, breakage, proliferation, and subsequent degeneration of fragments resulted in dwarf embedded Fucus populations, with their stature being comparable to in situ populations at the 25 sites. Although detached and entangled $F$. s. ecad lutarius thalli were not found in the upper transplant studies, the morphological continuity between dwarf Fucus, F. s. ecad lutarius, and F. spiralis (see Figure 1) still suggests an interrelationship between the three taxa, like that observed by Baker and Bohling (1916) and Niell et al. (1980) between entangled and embedded forms of Fucus vesiculosus at different elevations. Such morphological gradations are obviously very complex and may involve hybridization (see below) and diverse environmental factors, including desiccation. The fact that in situ F. s. ecad lutarius usually occurs in the mid intertidal zone at Brave Boat Harbor (Mathieson and Dawes, 2001) suggests that it is sensitive to extreme desiccation (cf. Baker and Bohling 1916, Fritsch 1959). Hence if detached and fragmented thalli of $F$. spiralis had been maintained in the mid intertidal zone, a different pattern may have emerged.

Overall, the transplant studies confirmed pronounced variability of frond width and branching patterns that was probably due to phenotypic plasticity, the type of genetic material involved, and contrasting habitats. Several authors (Baker and Bohling 1916, Skrine 1928, Carter 1933, Lynn 1935, Naylor 1936 Mathieson and Dawes 2001) also suggest that desiccation and sediment type can modify fucoid morphology, resulting in a convergence of dwarf forms and the production of multiple ecads (Figure 1). In conducting a one year transplant study within a British salt marsh, Baker and Bohling (1916) found that transplants of attached F. vesiculosus produced vegetative proliferations, and that "after one or two vegetative generations, the characteristic marsh forms would be produced". Mathieson and Dawes (2001) confirmed similar findings after a one-year transplant study at Brave Boat Harbor. They stated that dwarf Fucus represented a phenotypic variant of $F$. spiralis caused by detachment, extensive proliferation, and degeneration of detached fragments.

Several other points should be noted regarding the multi-year transplant study. Foremost, some major morphological changes did occur within one year, including the transformation of dwarf Fucus into $F$. spiralis ecad lutarius, as well as the breakage, diminishment, and fragmentation of attached $F$. spiralis, leading to dwarf Fucus. The process of dichotomic splitting (Den Hartog, 1972) is a critical step in the formation of dwarf Fucus from attached parental material. As noted by Norton and Mathieson (1983), the survival of embedded forms of Fucus depends primarily upon vegetative propagation and the ability of fragments to grow upwards at least as fast as the rate of sedimentation. Dwarf Fucus is a slow growing perennial that is not found in the wetter parts of salt marshes where rates of rotting and silt deposition are greatest (Mathieson and Dawes, 2001). The biomass patterns for transplant material also showed conspicuous changes. For example, the biomass of low transplants of dwarf Fucus decreased to less than $15 \%$ of original weights after 3 years, no doubt in part due to intense competition with F. spiralis (Chapman 1995). Dwarf Fucus populations resulting from upper transplants showed a rapid increase in biomass $(506.4 \pm 0 \mathrm{~g}$ dry wt. $\mathrm{m}$ ) after one year, exceeding contiguous in situ populations; after three years they had a more "typical biomass" of $221.9 \pm 110.5 \mathrm{~g}$ dry wt. $\mathrm{m}^{-2}$ and were still mixed with $F$. spiralis. Microscopic germlings of $F$. spiralis, that were apparently moved from the mid to the upper intertidal zone, were still present as mixed populations after three years, but were absent from the in situ high intertidal site. Although no in situ populations of dwarf Fucus were found in the mid-intertidal zone, $F$. s. ecad lutarius was often present in this zone at Brave Boat Harbor (Mathieson and Dawes, 2001).

Based on the above described transect, biomass, and transplant studies, several interesting patterns regarding salt marsh fucoid biomass can be noted. Foremost, the abundance of dwarf Fucus was relatively high, particularly in "Downeast", Maine where mean and maximum biomass values of $\sim 800$ and $2100 \mathrm{~g}$ dry wt. $\mathrm{m}^{-2}$ were found at Reversing Falls (site 1), while Moose Cove (site 2) had an almost identical mean biomass $(790 \pm 109 \mathrm{~g}$ dry wt. $\mathrm{m}^{-2}$ ). One mid coastal area in Maine (Basin Cove, site 7) also had a very high biomass value of $\sim 1200 \mathrm{~g}$ dry wt. $\mathrm{m}^{-2}$. Typically, most other dwarf Fucus populations had lower biomass values (mean $=451.5 \pm 242.5 \mathrm{~g}$ dry wt. $\mathrm{m}^{-2}$ ), with similar values in "newly" developed transplant populations at Brave Boat Harbor. A comparison of biomass patterns for dwarf Fucus shows that they are comparable or greater than those of other salt marsh seaweeds and flowering plants, except for red fescue (i.e., Festuca rubra). By contrast, fucoid algae growing in rocky areas typically have a much higher biomass than those found in salt marshes (Lüning 1990, Round 1981). For example, intertidal saxicolous populations of Ascophyllum nodosum within the Great Bay Estuary System of Maine and New Hampshire have a mean biomass of $2073 \mathrm{~g}$ dry wt. $\mathrm{m}^{-2}$, with $F$. vesiculosus var. spiralis and A. nodosum ecad scorpioides having $50 \%$ or less (Nelson et al. 1982, Chock and Mathieson 1983). Higher biomass values $\left(\sim 3200 \mathrm{~g}\right.$ dry $\left.w \mathrm{w} . \mathrm{m}^{-2}\right)$ are recorded for $A$. nodosum and $F$. vesiculosus populations from several coastal areas of Maine (Topinka et al. 1981).

Molecular studies indicate that morphological differences between Fucus spiralis and F. vesiculosus correspond to genetic variations between these species at five microsatellite loci. While genetically distinct from each other, genotype clusters of both taxa overlap with the cluster of $F$. spiralis ecad lutarius genotypes, which in turn overlaps the cluster of dwarf embedded Fucus genotypes. A relationship between saxicolous and dwarf genotypes is predictable, as dwarf populations are ultimately derived from saxicolous species, but the intermediate position of the dwarf genotype cluster and small degree of overlap relative to the putative parental clusters is interesting. The most straightforward hypothesis, which obviously requires further testing, is that only a few "pure" saxicolous genotypes persist as ecad lutarius upon detachment and almost none are capable of per- 
sisting for extended periods of time upon conversion to a dwarf embedded state. Thus, genetic distinctiveness of dwarf morphologies may well be due to habitat-related selection between saxicolous and dwarf habitats. Wallace et al. (2004) discussed this hypothesis in relation to dwarf Fucus in Brave Boat Harbor (site 14), which they found to be of hybrid origin between $F$. vesiculosus and F. spiralis. Several earlier morphological studies have concluded that hybridization is frequent when F. vesiculosus and F. spiralis grow together (Kniep 1925, Burrows and Lodge 1951, Boney 1966, Scott and Hardy 1994). Recent molecular studies by Engel et al. (2005) confirm that natural hybridization occurs between dioecious $F$. vesiculosus and hermaphroditic F. spiralis in Portugal; their studies point to interspecific hybridization as the origin of genetically intermediate individuals. The genetic comparisons presented here for the Gulf of Maine are consistent with previous studies at Brave Boat Harbor (Wallace et al. 2004), which suggest a hybrid origin for dwarf populations, our third hypothesis. Genotype comparisons of dwarf embedded forms from the same geographic region support the morphological and transplant data presented here in arguing for their recognition as a distinct taxonomic unit (see below). The genetic studies also supports the assertion (Wallace 2005, Wallace et al. 2005) that morphologically similar dwarf populations worldwide should not be confused under a single taxonomic heading. Thus, dwarf embedded $F$. cottonii from Ireland is likely derived from $F$. vesiculosus and not the result of hybridization of $F$. vesiculosus and $F$. spiralis like those from the northwest Atlantic Ocean (Wallace 2005, Wallace et al. 2005). Also, F. "cottoni-type" in the Northeast Pacific Ocean is probably derived from $F$. gardneri (Kucera and Saunders 2006, Serrão et al. 2006).

There have been contrasting interpretations regarding the derivation of dwarf embedded Fucus in Brave Boat Harbor, Maine. Based on morphological and transplant studies, Mathieson and Dawes (2001) concluded that it was derived from $F$. spiralis, while molecular studies by Wallace et al. (2004) suggested a hybrid origin. The latter authors have suggested two reasons for the apparent discrepancy. First, studies of Wallace et al. (2004) showed that " $F$. spiralis" genotypes were sometimes present within the muscoides-like Fucus cloud of their FCA and may have been of hybrid origin. Such hybrids might therefore account for much of the dwarf material observed in reciprocal transplants, with non-hybrid F. spiralis making a proportionately smaller contribution. Correlated with this hypothesis is the difficulty of tracking the contributions of individual founder events to the long term survival of embedded dwarf forms, although the high proportion of apparent hybrids suggests that hybrids may have an advantage in ecad-forming environments. In comparing $F$. spiralis populations from Brave Boat Harbor with those characterized in Table 1, it is apparent that they possess several typical features (spiraled thalli, absence of vesicles, hermaphroditic reproduction, cryptostomata, and a sterile receptacular rim), while their stature, branching pattern, and habitat are somewhat different. In particular they are smaller, less spiraled, less branched, and occur on sandy rather than rocky substrata (Newton 1931, Taylor 1962, Niemeck and
Mathieson 1976, Mathieson et al. 2001). By contrast, $F$. spiralis thalli from muddy estuarine habitats like the Great Bay Estuary of New Hampshire/Maine are obligate lithophytes that only grow on coarse metasedimentary and metavolcanic rocks (Niemeck and Mathieson 1976). Hence, these lithophytes may be genetically different from those in sandy salt marsh habitats.

Finally, much uncertainty still exists regarding several salt marsh fucoid taxa. For example, the term ecad may be inappropriately used to designate some entangled and embedded Fucus taxa in the Gulf of Maine ( $F$. spiralis ecad lutarius and $F$. vesiculosus ecad volubilis), as their morphological and ecological differences may reflect underlying genetic differences (Wallace 2005). By contrast, some taxa designated as forma (e.g. F. vesiculosus f. mytili) may represent phenotypic variants that are really ecads. Hence, the genetic traits for several of these salt marsh Fucus taxa need to be carefully documented prior to any final taxonomic resolution.

\section{Acknowledgements}

We thank Professor Michael Guiry (University College, Galway, Ireland) who was very helpful to CJD by supplying maps, helping to evaluate an initial study site, and providing directions to two other locations in Galway Bay. We also thank Michael W. Hawkes and Sandra Lindstrom for the loan of Alaskan dwarf embedded Fucus specimens from the Algal Herbarium at the University of British Columbia (UBC). Published as Scientific Contribution Number 2309 from the New Hampshire Agricultural Experiment Station; also issued Contribution Number 422 from the Jackson Estuarine Laboratory and Center for Marine Biology. We acknowledge NOAA Sea Grant (project \#111371), the USDA $\mathrm{NH}$ Agriculture Experiment Station (Hatch \#11H536), and funds from the Hubbard Marine Endowment at the University of New Hampshire.

\section{References}

Anderson, C.I. and G.W. Scott. 1998. The occurrence of distinct morphotypes within a population of Fucus spiralis. J. Mar. Biol. Assoc. U. K. 78: 1003-1006.

Baker, S.M. and M.H. Bohling. 1916. On the brown seaweeds of the salt marsh. Part II. Their systematic relationships, morphology, and ecology. J. Linn. Soc. Bot. 43: 325-380.

Belkhir, K. 1999. Genetix 4.0. Laboratoire Genome, Populations, CNRS UPR 9060.

Bolwell, G.P., J.A. Callow, M.E. Callow and L.V. Evans. 1977. Cross-fertilization in fucoid seaweeds. Nature 268: 626-627.

Boney, A.D. 1966. A biology of marine algae. Hutchinson Educational Ltd., London. pp. 216.

Brinkhuis, B.H. 1976. The ecology of temperate salt-marsh fucoids. I. Occurrence and distribution of Ascophyllum nodosum ecads. Mar. Biol. 34: 325-338.

Burrows, E.M. and S. Lodge. 1951. Autecology and the species problem in Fucus. J. Mar. Biol. Assoc. U. K. 30: 161-176.

Carter, N. 1933. A comparative study of the algal flora of two salt marshes. Part II. J. Ecol. 21: 128-208.

Chapman, A.R.O. 1995. Functional ecology of fucoid algae: twenty-three years of progress. Phycologia 34: 1-32.

Chapman, V.J. 1939. Some algal complexities. Rhodora 41: 19-27.

Chapman, V.J. 1940. Studies in salt marsh ecology. Sections VI and VII. Comparison with marshes on the east coast of North America. J. Ecol. 28: 118-152. 
Chapman, V.J. and D.J. Chapman. 1973. The algae. Macmillan and Co. Ltd., New York. pp. 497.

Chock, J.S. and A.C. Mathieson. 1976. Ecological studies of the salt marsh ecad scorpioides (Hornemann) Hauck of Ascophyllum nodosum (L.) Le Jolis. J. Exp. Mar. Biol. Ecol. 23: 171-190.

Chock, J.S. and A.C. Mathieson. 1983. Variations of New England estuarine seaweed biomass. Bot. Mar. 26: 87-97.

Clements, F.E. 1905. Research methods in ecology. Lincoln University Publishing Co., Lincoln, Nebraska. pp. 530.

Collins, F.S. 1900a. Notes on algae, II. Rhodora 2: 11-14.

Collins, F.S. 1900b. Preliminary lists of New England plants V. Marine algae. Rhodora 2: 41-52.

Collins, F.S. 1906. New species, etc., issued in the Phycotheca Boreali-Americana. Rhodora 8: 104-113.

Colt, L.C., Jr. 1999. A guide to the algae of New England. Part I introduction, section I: the New England region. PIP Printers, Walpole, Mass. pp. 519

Cotton, A.D. 1912. Marine algae. In: (R. L. Praeger, ed). A biological survey of Clare Island in the County of Mayo, Ireland and the adjoining district. Section 1, part 15. Hodges, Figgis and Co. Ltd., Dublin, Ireland. pp. 1-178.

Coyer, J.A., A.F. Peters, G. Hoarau, W. T. Stam and J.L. Olsen. 2002. Hybridization of the marine seaweeds, Fucus serratus and Fucus evanescens (Heterokontophyta: Phaeophyceae) within a 100-year-old zone of secondary contact. Proc. $R$. Soc. Lond. 269: 1829-1834.

Davy de Virville, A. 1944. Les Fucus des côtes des France. Rev. Sci., Paris, 3237-3238: 421-452.

Dawes, C.J. 1998. Marine botany. 2nd edition. John Wiley and Sons Inc., New York. pp. 480.

Den Hartog, C. 1959. The epilithic algal communities occurring along the coast of the Netherlands. Wentia 1: 1- 241.

Den Hartog, C. 1972. Substratum plants- multicellular plants. In: (O. Kinne, ed.) Marine ecology. Vol. 1: Environmental factors, part 3. Wiley- Interscience, London. pp. 1277-1289.

Engel, C.R., S.H. Brawley, K.J. Edwards and E. Serrão. 2003. Isolation and cross-species amplification of microsatellite loci from the fucoid seaweeds Fucus vesiculosus, F. serratus, and Ascophyllum nodosum. Mol. Ecol. Notes 3: 180-182.

Engel, C.R., C. Daguin and E.A. Serrão. 2005. Genetic entities and mating system in hermaphroditic Fucus spiralis and its close dioecious relative F. vesiculosus (Fucaceae, Phaeophyceae). Mol. Ecol. 14: 2033-2046.

Evans, L.V., J.A. Callow and M.E. Callow. 1982. The biology and early biochemistry of reproduction and development in Fucus. In: (F.E. Round and D. J. Chapman, eds) Progress in phycological research. Vol. 1. Elsevier, Amsterdam. pp. 68108.

Feldmann, J. and F. Magne. 1964. Addition'à l'inventaire de la flore marine de Roscoff: algues, champignons, lichens. Édition de la Station Biologique de Roscoff. pp. 28.

Fritsch, F.E. 1959. The structure and reproduction of the algae. Vol. 2 Foreword, Phaeophyceae, Rhodophyceae, Myxophyceae. Cambridge University Press, Cambridge, UK. pp. 939.

Gibb, D.C. 1957. The free-living forms of Ascophyllum nodosum (L.) Le Jol. J. Ecol. 45: 49-83.

Hardy, F.G., G.W. Scott, P.R. Sisson, N.F. Lightoot and M. Mulyadi. 1998. Pyrolysis mass spectrometry as a technique for studying inter- and intraspecific relationships in the genus Fucus. J. Mar. Biol. Assoc. U. K. 78: 35-42.

Kalvas, A. and L. Kautsky. 1993. Geographical variation in Fucus vesiculosus morphology in the Baltic and North Seas. Eur. J. Phycol. 28: 85-91.

Kalvas, A. and L. Kautsky. 1998. Morphological variation in Fucus vesiculosus populations along temperature and salinity gradients in Iceland. J. Mar. Biol. Assoc. U. K. 78: 985-1001.

Kniep, H. 1925. Über Fucus-Bastarde. Flora 118-119: 331-338.

Kotulas, G. 1989. Differentiation geographique et structure genetique des populations de Solea vulgaris. Ph.D. thesis, University of Montpellier II, France. pp. 138.
Kucera, H. and G.W. Saunders. 2005. Resolving species limits for the brown algal genus Fucus in the Northeast Pacific. In: Program and Abstracts Northeast Algal Society Meeting, Rockport, Maine, 15-17 April, 2005. p. 15.

Kucera, H. and G.W. Saunders. 2006. Molecular analysis of species limits of the brown algal genus Fucus in the Northeast Pacific. In: Program and Abstracts Northeast Algal Society Meeting, Poughkeepsie, NY, 21-23 April, 2006. p. 27.

Leclerc. C., V. Barriel, G. Lecointre and B. De Reviers. 1998. Low divergence in rDNA ITS sequences among five species of Fucus (Phaeophyceae) suggests a very recent radiation. $J$. Mol. Ecol. 46: 115-120.

Lüning, K. 1990. Seaweeds: their environment, biogeography, and ecophysiology. Wiley-Interscience, New York. pp. 527.

Lynn, M.J. 1935. Rare algae from Strangford Lough. Part 1. Irish Naturalists J. 5: 201-208.

Marsden, W.J.N., L.V. Evans and J.A. Callow. 1983. Analysis of character variation in Fucus L. Bot. Mar. 26: 383-392.

Mathieson, A.C. and C.J. Dawes. 2001. A muscoides-like Fucus from a Maine salt marsh: its origin, ecology, and taxonomic implications. Rhodora 103: 172-201.

Mathieson, A.C. and R.A. Fralick. 1972. Investigations of New England marine algae $V$. The algal vegetation of the Hampton-Seabrook Estuary and the open coast of Hampton, New Hampshire. Rhodora 74: 406-435.

Mathieson, A.C. and E.J. Hehre. 1986. A synopsis of New Hampshire seaweeds. Rhodora 88: 1-139.

Mathieson, A.C. and C.A. Penniman. 1986a. A phytogeographic interpretation of the marine flora from the Isles of Shoals, U.S.A. Bot. Mar. 29: 413-434.

Mathieson, A.C. and C.A. Penniman. 1986b. Species composition and seasonality of New England seaweeds along an open coastal-estuarine gradient. Bot. Mar. 29: 161-176.

Mathieson, A.C. and C.A. Penniman. 1991. Floristic patterns and numerical classification of New England estuarine and open coastal seaweed populations. Nova Hedwigia 52: 453-485.

Mathieson, A.C., T.A. Norton and M. Neushul. 1981. The taxonomic implications of genetic and environmentally induced variations in seaweed morphology. Bot. Rev. 47: 313-347.

Mathieson, A.C., E.J. Hehre and M. Costa. 1993. Algal vegetation of the York River Estuary and the adjacent open coast of southern Maine. Rhodora 95: 285-324.

Mathieson, A.C., E.J. Hehre, J. Hambrook and J. Gerweck. 1996. A comparison of insular seaweed floras from Penobscot Bay, Maine, and other northwest Atlantic islands. Rhodora 98: 369-418.

Mathieson, A.C., C.J. Dawes and E.J. Hehre. 1998. Floristic and zonation studies of seaweeds from Mount Desert Island, Maine: a historical comparison. Rhodora 100: 333-379.

Mathieson, A.C., C.J. Dawes, M.L. Anderson and E.J. Hehre. 2001. Seaweeds of the Brave Boat Harbor salt marsh and adjacent open coast of southern Maine. Rhodora 103: 1-46.

Mathieson, A.C., C.J. Dawes, L.G. Harris and E.J. Hehre. 2003. Expansion of the Asiatic green alga Codium fragile subsp. tomentosoides in the Gulf of Maine. Rhodora 105: 1-53.

McLachlan, J., L.C.M. Chen and T. Edelstein. 1971. The culture of four species of Fucus under laboratory conditions. Can. J. Bot. 49: 1463-1469.

Munda, I.M. and B.P. Kremer. 1997. Morphological variation and population structure of Fucus spp. (Phaeophyta) from Helgoland. Nova Hedwigia 64: 67-87.

Naylor, G.L. 1936. The fucoids of St John's Lake, Plymouth, including a hitherto undescribed form of Fucus spiralis. Rev. Algol. 7: 425-439.

Nelson, J.I., Jr., J. Falicon, G. Lamb, D. Miller and S. Perry. 1982. Great Bay Estuary monitoring survey. Publications of the New Hampshire Fish and Game Department and Office of State Planning, Concord, New Hampshire. pp. 199.

Newton, L. 1931. A handbook of the British Seaweeds. British Museum (Natural History), London. pp. 478. 
Niell, F.X., A. Miranda and J.P. Pazo. 1980. Studies on the morphology of the megaecad limicola of Fucus vesiculosus $\mathrm{L}$. with taxonomical comments. Bot. Mar. 23: 303-307.

Niemeck, R.A. and A.C. Mathieson. 1976. An ecological study of Fucus spiralis L. J. Exp. Mar. Biol. Ecol. 24: 33-48.

Norton, T.A. and A.C. Mathieson. 1983. The biology of unattached seaweeds. In: (F.E. Round and D.J. Chapman, eds) Progress in phycological research. Vol. 2. Elsevier, Amsterdam. pp. 333-386.

Norton, T.A., A.C. Mathieson and M. Neushul. 1981. Morphology and environment. In: (C.S. Lobban and M.J. Wynne, eds) The biology of seaweeds. Blackwell, Oxford, pp. 421-457.

O'Clair, R.M. and S.C. Lindstrom. 2001. North Pacific seaweeds. Plant Press, Auke Bay, Alaska. pp. 159.

Parke, M. and P.S. Dixon. 1976. Check-list of British marine algae. Third revision. J. Mar. Biol. Assoc. U. K. 48: 783-832.

Parusel, E.S. 1991. Brown algae (Fucus vesiculosus f. mytili) entangled by blue mussels (Mytilus edulis) - a beneficial status of nutrient supply? British Phycol. J. 26: 93.

Pérez-Ruzafa, I.M. and T.G. García. 2000. In: (A.G. Garreta, ed.) Flora Phycologia Iberia. Vol. 1: Fucales. Universidad de Murcia. pp. 27-61.

Powell, H.T. 1963. Speciation in the genus Fucus L. and related genera. Systematics Association Publ. 5: 63-77.

Rice, E.R. and A.R.O. Chapman. 1985. A numerical taxonomic study of Fucus distichus (Phaeophyta). J. Mar. Biol. Assoc. U. K. 65: 33-59.

Round, F.E. 1981. The ecology of algae. Cambridge University Press, Cambridge. pp. 653.

Rosenvinge, L.K. 1898. Deuxième mémoire sur les algues marines du Groenland. Meddr. Grønland 20: 1-125.

Ruiz, G.M., P.W. Fofonoff, J.T. Carlton, M.J. Wonham and A.H. Hines. 2000. Invasion of coastal marine communities in North America: apparent patterns, processes, and biases. Ann. Rev. Ecol. Syst. 31: 481-531.

Russell, G. 1978. Environment and form in the discrimination of taxa in the brown algae. In: (D.E. Irvine and J.E. Price, eds) Modern approaches to the taxonomy of red and brown algae. Systematics Association Special Vol. 10. Academic Press, London. pp. 339-369.

Russell, G. 1987. Spatial and environmental components of evolutionary change: interactive effects of salinity and temperature on Fucus vesiculosus as an example. Helgol. Wiss. Meeresunters. 41: 371-376.

Russell, G. 1995. Pyrolysis mass spectrometry: a fresh approach to old problems in brown algal systematics? Mar. Biol. 123: 153-157.

Ruuskanen, A. and S. Bäck. 1999. Morphological variation of northern Baltic Sea Fucus vesiculosus L. Ophelia 50: 43-59.

Ruuskanen, A. and S. Bäck. 2002. Morphological changes in submerged Fucus vesiculosus L. (Phaeophyta) along the salinity gradient of the River Keret estuary, Russia. Sarsia 87: 185-188.

Sauvageau, C. 1907. Sur deux Fucus vivant sur le sable. C. $R$. Soc. Biol. Paris 63: 699-701.

Sauvageau, C. 1908a. Sur la stérilité et l'apogamie d'un Fucus vasicole et aérien. C. R. Soc. Biol. Paris 65: 64-65.

Sauvageau, C. 1908b. Sur deux Fucus récoltés à Arcachon (Fucus platycarpus et F. lutarius). Bull. Stat. Biol. Arcachon 11: $65-224$

Sauvageau, C. 1909. Sur l'hybride des Fucus vesiculosus et $F$. serratus. C. R. Soc. Biol. Paris, Ser. D, 67: 832-833.

Sauvageau, C. 1915. Sur une nouvelle espèce de Fucus, F. dichotomus Sauv. C. R. Acad. Sci. Biol. Paris 71: 11-14.

Sauvageau, C. 1923. A propos de quelques Fucus du Bassin d'Arcachon. Bull. Soc. Sci. Arcachon. Annèe. 20: 19-136.

Scagel, R.F., P.W. Gabrielson, D.J. Garbary, L. Golden, M.W. Hawkes, S.C. Lindstrom, J.C. Oliveira and T.B. Widdowson. 1993. A synopsis of the benthic marine algae of British Columbia, Southeast Alaska, Washington and Oregon. Phycological Contributions 3. University of British Columbia, Vancouver. pp. 535.
Schiller, J. 1909. Über Algentransport und Migrationsformationen im Meere. Int. Rev. Hydrobiol. 2: 62-98.

Scott, G.W. and F.G. Hardy. 1994. Observations of the occurrence of hybrids between two sympatric species of fucoid algae. Cryptogam., Algol. 15: 297-305.

Scott, G.W., J.H. Shaw, S.L. Hull, C. Pickart and A.M. Burlak. 2000. Some implications of plant size in monotypic and polytypic populations of Fucus spiralis. J. Mar. Biol. Assoc. U. K. 79: 359-360

Scott, G.W., S.L. Hull, S.E. Hornby, F.G. Hardy and N.J.P. Owens. 2001. Phenotypic variation in Fucus spiralis (Phaeophyceae): morphology, chemical phenotype and their relationship to the environment. Eur. J. Phycol. 36: 43-50.

Sears, J.R. 2002 (ed.). NEAS keys to benthic marine algae of the Northeastern Coast of North America from Long Island Sound to the Strait of Belle Isle. Northeast Algal Society Contribution 2. Dartmouth, MA. pp. 161

Serrão, E.A., L.A. Alice and S.H. Brawley. 1999. Evolution of the Fucaceae (Phaeophyceae) inferred from nrDNA-ITS. J. Phycol. 35: 382-394.

Serrão, E., M. Vliet, G.I. Hansen, C. Maggs and G. Pearson. 2006. Molecular characterization of the "cottoni" form of Fucus in the Northeastern Pacific versus the Atlantic. Meeting Progr., Phycol. Soc. Amer. 60th Ann. Meet., Juneau, Alaska, USA. p.75.

Sideman, E.J. and A.C. Mathieson. 1983. Ecological and genecological distinctions of a high intertidal dwarf form of Fucus distichus (L.) Powell. J. Exp. Mar. Biol. Ecol. 72: 171-188.

Sideman, E.J. and A.C. Mathieson. 1985. Morphological variation within and between natural populations of non-tide pool Fucus distichus (Phaeophyta) in New England. J. Phycol. 21: 250-257.

Skrine, P.M. 1928. A member of the Fucaceae from the Dovey salt marshes. J. Bot. 67: 241-243.

Skrine, P.M., L. Newton and E.H. Chater. 1932. A salt-marsh form of Fucus ceranoides L. from Llanbedr, Merioneth. Ann. Bot. 46: 769-779.

Smith, C.M. and L.J. Walters. 1999. Fragmentation as a strategy for Caulerpa species: fates of fragments and implications for management of an invasive weed. Mar. Ecol. Prog. Ser. 20: 307-319.

Taylor, W.R. 1962. Marine algae of the Northeastern Coast of North America. 2nd edition. University of Michigan Press, Ann Arbor. pp. 509.

Thuret, G. 1854. Recherches sur la fécondation des Fucacaées. Annales des Sciences Naturelles, Botanique, Série 4, 2: 197-214.

Topinka, J., L. Tucker and W. Korjeff. 1981. The distribution of fucoid macroalgal biomass along central coastal Maine. Bot. Mar. 24: 311-319.

Torrey, J.G. and E. Galun. 1970. Apolar embryos of Fucus resulting from an osmotic chemical treatment. Amer. J. Bot. 57: 111-119.

Wallace, A. 2005. The taxonomic and systematic relationships of several salt marsh Fucus taxa (Heterokontophyta, Phaeophyceae) within the Gulf of Maine and Ireland examined using microsatellite markers. Ph.D. thesis, University of New Hampshire, Durham, NH. pp. 225.

Wallace, A., A.S. Klein, and A.C. Mathieson. 2004. Determining the affinities of salt marsh fucoids using microsatellite markers: evidence of hybridization and introgression between two species of Fucus (Phaeophyta) in a Maine estuary. J. Phycol. 40: 1013-1027.

Wallace, A., A.S. Klein and A.C. Mathieson. 2005. The genetic affinities of Fucus cottonii Wynne et Magne from Ros Muc, Ireland. In: Program and Abstracts Northeast Algal Society Meeting, Rockport, Maine, 15-17 April, 2005. p. 39.

Wynne, M.J. and F. Magne. 1991. Concerning the name Fucus muscoides (Cotton) J. Feldmann et Magne. Cryptogam., Algol. 12: 55-65.

Received 5 August, 2005; accepted 25 May, 2006 